\title{
O SOFISTYCE WSPÓŁCZESNEGO DYSKURSU HUMANISTYCZNEGO - TRADYCJE, POSTKOLONIALNE UWIKŁANIA, KONSEKWENCJE
}

\author{
MARTA SKWARA, MAREK SKWARA ${ }^{1}$ \\ (Uniwersytet Szczeciński)
}

Słowa kluczowe: humanistyka, studia postkolonialne, recepcja, neopragmatyzm, tropologia, sofistyka, dyskurs ponowoczesny, neostalinizm

Keywords: humanities, postcolonial studies, reception studies, neopragmatism, tropology, sophistry, postmodern discourse, neostalinism

\begin{abstract}
Abstrakt: Marta Skwara, Marek Skwara, O SOFISTYCE WSPÓŁCZESNEGO DYSKURSU HUMANISTYCZNEGO - TRADYCJE, POSTKOLONIALNE UWIKŁANIA, KONSEKWENCJE. „PORÓWNANIA" 15, 2014, T. XV, s. 45-74. ISSN 1733-165X. Celem artykułu jest analiza współczesnego dyskursu humanistycznego w Polsce, w którym szczególną rolę odgrywają: kondycja postkolonialna, trzecia sofistyka i zaplecze ideologiczne systemu komunistycznego. Miękkie przejścia od "starych” tez marksistowskich do „współczesnego" relatywizmu i, szerzej, postmodernizmu było możliwe między innym dzięki recepcji amerykańskiego neopragmatyzmu, a zwłaszcza poglądów etycznych Stanleya Fisha i Richarda Rorty'ego. Narzędzi językowych pomocnych w opisie zrelatywizowanego świata dostarczyła trzecia sofistyka (czyli współczesna wersja pierwszej sofistyki greckiej reprezentowanej przez Gorgiasza, czy Protogorasa). Autorzy stawiają tezę, że dziedzictwo sowieckiego kolonializmu sprawiło, iż ponowoczesny dyskurs polski zasadza się na manipulacjach wywodzących się z czasów stalinizmu. Nowy system i nowa ideologia wykorzystują stare chwyty wciąż głęboko tkwiące w świadomości uczestników publicznej debaty w Polsce.
\end{abstract}

Abstract: Marta Skwara, Marek Skwara, ON THE SOPHISTRY OF A MODERN HUMANISTSIC DISCOURSE - TRADITIONS, POSTCOLONIAL IMPLICATIONS, CONSEQUENCES. "PORÓWNANIA" 15, 2014, Vol. XV, p. 45-74. ISSN 1733-165X. The aim of the article is an analysis

${ }^{1}$ Correspondence Address: skwara@univ.szczecin.pl 
of a contemporary humanistic Polish discourse in which three elements play specific roles: a postcolonial condition, the third sophistry and the ideological background of the communist system. A soft switch from "old" Marxist theses to "modern" relativism, and, in a broader sense, to postmodernism became possible inter alia due to the reception of American neopragmatism, especially Stanley Fish's and Richard Rorty's ethical views. The third sophistry (a modern version of the first sophistry represented by Gorgias and Protagoras) delivered helpful language tools for a description of the world which became relativistic. The authors of the article propose a thesis that the heritage of the Soviet colonialism resulted in such a version of postmodern Polish discourse that is based on manipulations dating back to Stalinism. The new system and new ideology have made use of the old tricks that are still deeply rooted in the mentality of the participants of the public debate in Poland.

Nasza próba zdiagnozowania istotnych aspektów dyskursu humanistycznego w Polsce obejmuje zarówno wymiar popularny i medialny, jak i popularnonaukowy oraz naukowy, a o wyborze tak szeroko zakrojonego obszaru badań zadecydowało podstawowe narzędzie, którym się posługujemy (retoryka) oraz tożsamość opisywanych zjawisk na wszystkich badanych poziomach (których uczestnicy, co nie najmniej istotne, także bywają tożsami). Bierzemy przede wszystkim pod uwagę trzy istotne elementy składowe tego dyskursu.

Punktem wyjścia jest postkolonialność, która - naszym zdaniem - określa zarówno kondycję państwa polskiego po przemianach 1989 roku, jak i diagnozuje stan mentalności części członków opiniotwórczej elity narodu². Trudno byłoby przeczyć, że wielu reprezentantów tej elity, ciągle mających wpływ na opinię publiczną, wywodzi się z elit Polski komunistycznej, niektórzy z nich byli beneficjentami komunizmu, inni wyrośli w środowiskach jego silnego oddziaływania. Przemiany polityczne wymusiły zmianę (często tylko werbalną) postaw badawczych, metodologii, filozofii, strategii medialnych. Używając powszechnie znanej już dziś metafory, można powiedzieć, iż propagowanie i narzucanie jedynej słusznej ideologii zostało zastąpione przez bardziej miękkie sugerowanie (przekonywanie, namawianie do) „nowoczesnych” (w znaczeniu: „ponowoczesnych”) postaw relatywistycznych, "obowiązujących” w filozofii, etyce, życiu społecznym. Taka strategia dociera do kolejnego pokolenia, pozbawionego rzeczywistych doświadczeń historycznych, a chętnie podążającego za modą sprzyjającą szcze-

\footnotetext{
${ }^{2}$ Nasze stanowisko jest tu bliskie diagnozom Ewy Thompson zob. E. Thompson, Postkolonialne refleksje. Na marginesie pracy zbiorowej "From Sovietology to Postcoloniality: Poland and Ukraine from a Postcolonial Perspective" pod redakcja Janusza Korka. „Porównania” 2008, nr 5, s. 113-125. „Zniewolenie przez Sowiety" - jak to ujmuje Autorka - nie odbywało się bowiem poprzez obce osadnictwo, rządy obcych namiestników, czy podporządkowanie rasowe, ale poprzez "skolonizowanie polskich umysłów".
} 
gólnie poglądom określanym jako: „najnowsze”, „współczesne” czy „postępowe" 3 . Doskonałym narzędziem, które umożliwiło taką przemianę, była/jest trzecia sofistyka i jej podbudowa filozoficzna, czyli recepcja neopragmatyzmu amerykańskiego.

Trzecia sofistyka, która współcześnie oznacza wszelkiego rodzaju manipulacje retoryczne i erystyczne, jest kontynuacją pierwszej sofistyki greckiej (poprzez bezpośrednie nawiązania do myśli Protagorasa i Gorgiasza) ${ }^{4}$, rzadziej widoczne są w niej odwołania do drugiej sofistyki (umownie przyjmuje się, iż funkcjonowała ona w Rzymie w latach 50-400 w. n.e., jej stolicą była Smyrna). ${ }^{5}$ Podstawowymi cechami myślenia obowiązującego $\mathrm{w}$ ramach trzeciej sofistyki są: dominacja retoryki nad logiką; wypieranie prawdy (szczególnie Prawdy niedającej się zrelatywizować) przez prawdopodobieństwo; relatywizm epistemologiczny i etyczny (sytuacyjność myśli i sądów); równoprawność rozmaitych, nawet przeciwstawnych opinii, co oznacza, iż klasyczne prawo logiczne: $\mathrm{A} \neq \sim \mathrm{A}$ przybiera postać: $\mathrm{A}=\sim \mathrm{A}^{6}$.

\footnotetext{
${ }^{3}$ Jest to przykład działania sofizmatu argumentacyjnego, często wykorzystywanego przez reklamę: "coś jest słuszne lub dobre tylko dlatego, że jest nowe”. B. Witkowska-Maksimczuk, Elementy retoryki i erystyki w przykładach. Warszawa 2014, s. 169. Zob. także P. H. Lewiński, Neosofistyka. Argumentacja retoryczna $w$ komunikacji potocznej. Wrocław 2012, s. 179.

${ }^{4}$ Zob. M. Skwara, Między sofistyka a neopragmatyzmem, czyli o „etyce sytuacyjnej”. W: Retoryka $i$ etyka. Pod red. B. Sobczak i H. Zgółkowej. Poznań 2009, s. 59 in. (tu też wybrana bibliografia). W literaturze polskiej - na określenie wszelkiego rodzaju manipulacji występujących w szeroko rozumianym współczesnym życiu społecznym - funkcjonuje zarówno określenie "trzecia sofistyka” jak i "neosofistyka”, zob. P. H. Lewiński, Neosofistyka. Argumentacja retoryczna w komunikacji potocznej. Wrocław 2012. Bardziej fortunne, bo wyraźnie wskazujące na ciągłość historyczną, wydaje się nam określenie „trzecia sofistyka”.

${ }^{5} \mathrm{O}$ „drugiej sofistyce” zob. M. Skwara, Między sofistyka a neopragmatyzmem, czyli o „etyce sytuacyjnej", op. cit., s. 47 in., tu też wybrana bibliografia.

${ }^{6}$ Przykładem takiego zjawiska jest słynne, z reguły traktowane jedynie jako zabawny lapsus, powiedzenie Lecha Wałęsy: „Jestem za, a nawet przeciw”. Monteskiusz znakomicie pokazal, jak jednoczesne funkcjonowanie przeciwnych sądów obowiązywało w ramach „drugiej sofistyki”: „Kaligula był prawdziwym sofistą w swym okrucieństwie. Jako że pochodził on zarówno od Antoniusza jak i Augusta, orzekł że ukarze konsulów, jeśliby obchodzili dzień radości ustanowiony na pamiątkę zwycięstwa pod Akcjum, i ukaże ich, jeśli nie będą go obchodzić. Gdy umarła Druzilla, której przyznał cześć boską, było zbrodnią płakać, gdyż była ona boginią, i nie płakać, gdyż była ona jego siostrą". Montesquieu (Charles de Secondat baron Montesquieu), Rozważania o przyczynach wielkości Rzymian i o ich upadku. Tłumaczenie i opracowanie L. Sługocki. Łódź 2000, s. 106. Warto zauważyć, że współczesny tłumacz dzieli się z czytelnikami taką oto refleksją historyczną: „W związku z dwusetną rocznicą śmierci Montesquieu odbyła się w Warszawie w październiku 1955 r. sesja naukowa zorganizowana przez Polską Akademię Nauk. [...] referaty, wystąpienia i dyskusje [...] czytać dziś można jedynie z prawdziwym zażenowaniem [...]. Polska międzywojenna była państwem faszystowskim. Marks, Engels, Lenin, Stalin, Bierut - to były autorytety, które cytowano, które wytyczały kierunek nauki” (s. 11). Na tej samej stronie tłumacz zamieszcza przypis informujący, że „Szereg tych naukowców kontynuowało dumnie swe kariery po 1989 r. Nawet zostawali członkami rzeczywistymi Polskiej Akademii Nauk".
} 
Trzecim elementem jest niedostrzegane, a co za tym idzie nienazwane, dziedzictwo stalinizmu obecne $\mathrm{w}$ sposobach myślenia i argumentacji współczesnej. John Radziejowski użył pojęcia neostalinizmu wobec postawy współczesnych amerykańskich historyków zajmujących się Holokaustem i relacjami polskożydowskim (piszemy o tym dokładnie w dalszej części artykułu). Problem, który analizujemy w tekście, dotyczy nie tylko zagadnień opisywania historii, ale całego typu dyskursu (a także postawy intelektualnej i moralnej), który wyrósł na gruncie postkolonialnym i powszechnie posługuje się manipulacjami typowymi dla trzeciej sofistyki. Dyskurs ten zasadza się na przekonaniu, że istnieje niewielka grupa wtajemniczonych (tu m.in. propagatorzy i strażnicy poprawności politycznej ${ }^{7}$, co jest lustrzanym odbiciem stalinowskiej metafory „inżynierów dusz”), którzy „wiedzą lepiej”, i reszty społeczeństwa, którą trzeba wyedukować; odrzucenie i odwracanie znaczenia kluczowych dla kultury narodowej terminów, np. „patriotyzm"; przypisywanie wszystkim przeciwnikom kompromitujących etykietek, z których najpopularniejsza to "faszysta", propagowanie postaw relatywistycznych z jednym zasadniczym wyjątkiem, który dotyczy Holokaustu ${ }^{8}$.

Zacznijmy od wyjaśnienia rodowodu pojęcia "trzecia sofistyka”. W ciągu ostatnich kilku dziesięcioleci do tego stopnia narastał sprzeciw wobec negatywnych opinii o sofistach, że Susan Jarratt i Victor Vitanza, zasugerowali, że żyjemy w czasach "trzeciej sofistyki" ${ }^{9}$. W polskiej nauce pogląd rehabilitacji sofistyki głosi m.in. Cyprian Mielczarski. Pisze on np.:

obecnie cywilizacja nasza przeżywa okres intensywnego wgłębiania się we własną egzystencję, ale z całkowitym i konsekwentnym pominięciem sfery transcendentnej. Ten aspekt obecnej kultury bardzo przypomina epokę sofistów, ponieważ oni właśnie zaczęli zajmować się człowiekiem, pomijając całą tę sferę, do której odwoływali się jońscy filozofowie przyrody ${ }^{10}$.

I dalej dopełnia:

Istnieje wiele podobieństw między nowymi tendencjami, jakie wnieśli do kultury klasyczni sofiści, a ewolucją intelektualną i obyczajową $\mathrm{w}$ naszych czasach. $\mathrm{W}$ istocie [...] obecny zwrot w kierunku zagadnień dotyczących tego, co, jakby powiedział Gombrowicz, "międzyludzkie" przypomina zwrot antropologiczny dokonany przez klasycznych sofistów ${ }^{11}$.

7 Zob.: M. Kacprzak, Pułapki poprawności politycznej. Radzymin 2012; A. Szahaj, E pluribus unum? Dylematy wielokulturowości i politycznej poprawności. Kraków 2010.

${ }^{8} \mathrm{O}$ manipulacjach Holokaustem zob. m.in. I. Zertal, Naród i śmierć. Zagłada w dyskursie i polityce Izraela. Przeł. J. M. Kłoczowski. Kraków 2010.

${ }^{9}$ Zob.: V. J. Vitanza, Critical Sub/Versions of the History of Philosophical Rhetoric. "Rhetoric Review” 1987, nr 6, s. 45; M. Skwara, Między sofistyka a neopragmatyzmem, czyli o „etyce sytuacyjnej”, op. cit., s. 59.

${ }^{10} \mathrm{C}$. Mielczarski, Idee społeczno-polityczne sofistów. U źródeł europejskiego pluralizmu politycznego. Warszawa 2006, s. 210-211.

${ }^{11}$ Ibidem, s. 212. 
Sofistyka i retoryka sofistyczna przeżywają dziś prawdziwy renesans, obie łączy wspólna podstawa, jaką jest społeczeństwo demokratyczne. W tym miejscu mogą pojawić się wątpliwości związane $z$ tym, iż retoryka to przede wszystkim sztuka słowa, a w społeczeństwie ponowoczesnym, na skutek działania etosu infantylizacji, słowa zostają wypierane i zastępowane przez obrazy. Zjawisko to opisuje Benjamin Barber:

Infantylizacja ogarnia całe społeczeństwo konsumpcyjne, co znajduje także wyraz w przedkładaniu obrazów nad słowa. Nie twierdzę, że słowa zawsze służą złożoności i poszukiwaniu prawdy - obraz może być wart tysiąc słów, a słowa bywają narzędziem uproszczenia, propagandy i manipulacji. Jednakże, ogólnie rzecz biorąc, instytucje demokratyczne, a także nauka, filozofia i literatura (a tym samym, rzec można, cywilizacja) ukształtowały się dzięki deliberacji i wspólnej rozmowie. Język zapewnia wspólny grunt (a także, co należy przyznać, wspólne zamroczenie). Prawdopodobnie odkrywa tyle prawdy - choćby było to niewiele - ile jesteśmy w stanie osiągnąć. Dzisiejsze upodobanie do obrazów rzadko w każdym razie oznacza, że cenimy je jako surogaty przekonującej potęgi języka. Częściej chodzi o jej obejście, o drogę na skróty, pominięcie dojrzałych sposobów komunikowania się, zarówno obrazkowych, jak i językowych ${ }^{12}$.

Wygłoszona przez Barbera pochwała komunikacyjnej funkcji słowa, ale także jego funkcji epistemologicznej, wydaje się być - z czego zapewne sam Barber nie byłby zadowolony - z ducha bardzo sofistyczna. Żyjemy w cywilizacji obrazkowej, co, oczywiście, nie ogranicza wszelkich funkcji retoryki. Sztuka ta znakomicie przystosowuje się do wszystkich dziedzin życia i do wszystkich okoliczności, co między innymi oznacza, iż istnieje retoryka obrazu, czy szerzej - wszystkich sztuk wizualnych. A więc wszystko to, co piszemy na temat retoryki słowa, doskonale pasuje i odnosi się do retoryki obrazu, a określenie "trzecia sofistyka" dotyczy wszystkich przejawów życia społeczeństwa ponowoczesnego. Powrót sofistycznej retoryki jest także odnowieniem amerykańskiego pragmatyzmu. To dzięki niej znów jest on interdyscyplinarny, podobnie jak odnowiona retoryka, która dotyczy wielu dziedzin współczesnej humanistyki.

Przyjrzymy się rozwojowi trzeciej sofistyki w świecie zachodnim, aby następnie zapytać, jakie przejawy tego zjawiska zaobserwować można w świecie, który nazywany bywa bądź to "postkolonialnym”, bądź "postzależnym” - już sama zmiana nazwy wydaje się zabiegiem sofistycznym. Można bowiem na nią spojrzeć jako na zmianę dostrzegającą Inność sowieckiej kolonii i związaną z tym potrzebę stworzenia innej metodologii (i takie badania mają oczywiście miejsce), ale także jako na werbalne osłabienie znaczenia "kolonii” - skoro blok sowiecki nie był kolonią, a był jedynie „zależny”, to można ową zależność dowolnie stopniować i relatywizować, zgodnie z duchem ponowoczesnego pragmatyzmu.

12 B. R. Barber, Skonsumowani. Jak rynek psuje dzieci, infantylizuje dorostych i połyka obywateli. Przeł. H. Jankowska. Warszawa 2009, s. 165. 
Zacznijmy od Paula K. Fayerabanda, zdeklarowanego antyfundamentalisty, jednego z prekursorów współczesnych związków sofistyki i neopragmatyzmu, który często powoływał się na przedstawicieli pierwszej sofistyki, na przykład następująco:

Zadaniem naukowca [...] nie jest już „poszukiwanie prawdy", „sławienie Boga”, „systematyzowanie obserwacji” lub „ulepszanie przewidywań". Są to wyłącznie uboczne skutki działalności, na której obecnie przede wszystkim koncentruje on swą uwagę, a która ma "uczynić ze słabszego przypadku mocniejszy" jak mawiali sofiści, i w ten sposób podtrzymać ruch całości ${ }^{13}$.

Feyerabend cytuje tu znaną sentencję Protagorasa: „słabszy argument uczynić silniejszym"14, czym amerykański filozof podkreśla znaczenie zarówno sztuki prowadzenia sporów, jak i retoryki we współczesnej metodologii nauk. W innym miejscu swojego traktatu Feyerabend zestawia ze sobą dwie teorie: platońską i sofistyczną, przy czym sympatia amerykańskiego filozofa lokuje się po stronie tej drugiej:

W starożytności relacja między nowymi bytami a znanym światem zdrowego rozsądku dała początek różnorodnym teoriom. Jedna z nich, którą nazwać można platonizmem, zakłada, że nowe byty są realne, podczas gdy byty zdroworozsądkowe są jedynie niedoskonałymi kopiami. Inna teoria, którą zawdzięczamy sofistom, uznaje, że obiekty naturalne są rzeczywiste, a obiekty matematyczne (obiekty „rozumu”) są ich uproszczonymi, nierealistycznymi wyobrażeniami. Te dwie teorie zastosowano także przy omawianiu różnicy między nową, dość abstrakcyjną ideą wiedzy, propagowaną przez Platona (lecz odkrytą już wcześniej), a zdroworozsądkową wiedzą owych czasów (Platon mądrze posługuje się zniekształconym wyobrażeniem drugiej, aby przydać powagi pierwszej). Tak oto bądź głoszono, że istnieje wyłącznie jedna prawdziwa wiedza, a ludzkie zapatrywania stanowią jedynie jej blade odbicie, bądź też uważano ludzkie zapatrywania za jedyną wiedzę autentyczną, a abstrakcyjną wiedzę filozofów za bezużyteczne mrzonki („Widzę konia, Platonie”, powiedział Antystenes, „lecz nigdzie nie widzę twego idealnego konia") ${ }^{15}$.

Warto przyjrzeć się w tym miejscu roli, jaką w poglądach współczesnych neopragmatystów, takich jak np. Richard Rorty ${ }^{16}$, czy Stanley Fish ${ }^{17}$ (do grona neo-

${ }^{13}$ P. K. Feyerabend, Przeciw metodzie. Przeł. S. Wiertlewski. Redakcja naukowa przekładu K. Zamiara. Wrocław 1996, s. 29. Polscy edytorzy tekstu Feyerabenda nie opatrzyli tego ewidentnego cytatu z Protagorasa żadnym komentarzem, co jest jednym z dowodów na pomijanie przez polskich filozofów tradycji sofistycznej i jej szczególnej roli we współczesnej myśli humanistycznej. Jest to tym bardziej znaczące, że sam Feyerabend w przyp. 9 na s. 231 napisał: „Poglądy Protagorasa zostały szczegółowo omówione w rozdziale 1, część 3ff, Farewell to Reason".

14 Zob. J. Gajda-Krynicka, Filozofia przedplatońska. Warszawa 2007, s. 217.

${ }_{15}$ P. K. Feyerabend, Przeciw metodzie, op. cit., s. 222.

${ }^{16}$ Richard Rorty uchodzi za jednego z największych filozofów końca XX i początku XXI wieku. Biogram Richarda Rorty'ego zob. R. Shusterman, „Rorty, Richard”. W: The Johns Hopkins Guide to Literary Theory \& Criticism. Ed. M. Groden and M. Kreiswirth. Baltimore 1993, s. 626-628. 
pragmatystów zalicza się także mniej w Polsce znanych: Susan Jarratt, Jaspera Neela, Edwarda Schiapa ${ }^{18}$, czy Josepha Margolisa ${ }^{19}$ ), odgrywa retoryka.

Ponieważ poglądy Rorty'ego zyskały sobie bogatą polską recepcję, posłużymy się od razu omówieniem, wskazującym na duży stopień przyswojenia jego poglądów $w$ Polsce, przy jednoczesnym małym rozpoznaniu związków jego myśli z sofistyką. Według Andrzeja Szahaja, Rorty dostrzega w dziejach kultury dwa okresy: normalny i rewolucyjny. Ten pierwszy okres

w kulturze (nowożytnej) charakteryzuje się dużym stopniem zgodności co do tego, jakie zdania (sądy) są kandydatami na zdania (sądy) prawdziwe, a także względną skutecznością stosowania argumentacji odwołującej się do logiki oraz stabilnych założeń wstępnych, przyjmowanych najczęściej milcząco ${ }^{20}$.

Okres rewolucyjny z kolei „to [...] czas, w którym stabilności brakuje. [...] $\mathrm{W}$ tej sytuacji siła argumentacji odwołującej się do logiki zostaje zastąpiona siłą retorycznych zabiegów, korzystających z całego zestawu chwytów perswazyjnych"21. Wizja dziejów kultury według Rorty'ego, przynajmniej jeśli chodzi o argumentację, to rywalizacja między logiką i retoryką. Efektem logiki jest prawda, a retoryki - prawdopodobieństwo, a więc z jednej strony - pewność i stabilna wizja świata, z drugiej zaś - ciągły ruch na osi prawdopodobieństwa i, oczywiście, brak pewności. Jednocześnie, na co zwraca uwagę m.in. Jerzy Ziomek w swych pracach o retoryce, kruche prawdopodobieństwo jest często skuteczniejsze perswazyjnie niż tzw. najprawdziwsza prawda.

Andrzej Szahaj relację między „Prawdą" a retoryką w poglądach Rorty'ego ujmuje następująco: „zamiast dowodzić Prawdy, jesteśmy zmuszeni do przekonywania o słuszności naszego punktu widzenia. Uznanie zaś tego faktu pokazuje nam nieuniknioność retoryki jako sztuki perswazji wyrażającej podstawowy modus naszego wzajemnego obcowania"22. Z kolei Rorty pisze:

${ }^{17}$ Znany w Polsce przede wszystkim dzięki zbiorowi tekstów: S. Fish, Interpretacja, retoryka, polityka. Eseje wybrane. Pod red. A. Szahaja. Wstęp do polskiego wydania esejów R. Rorty. Przedmowa A. Szahaj. Kraków 2002. Biogram Stanleya Fisha zob. R. W. Dasenbrock, „Fish, Stanley”. In: The Johns Hopkins Guide to Literary Theory \& Criticism. Ed. M. Groden and M. Kreiswirth. Baltimore 1993, p. 273-276.

${ }^{18}$ Zob. m.in. E. Schiappa, Protagoras and logos. A Study in Greek Philosophy and Rhetoric. University of South Carolina. 1991. Ed. II - 2003.

${ }^{19}$ Zob. J. Margolis, Relatywizm i względność kulturowa. Tłum. M. Jakubczak. W: Idem, Czym, w gruncie rzeczy, jest dzieło sztuki? Wykłady z filozofii sztuki. Redakcja naukowa K. Wilkoszewska. Kraków 2004. Zob. także: J. Margolis, The Truth about Relativism. Oxford 1991.

20 A. Szahaj, Ironia i mitość. Neopragmatyzm Richarda Rorty’ego w kontekście sporu o postmodernizm. Warszawa 1996, s. 59.

${ }^{21}$ Ibidem.

22 A. Szahaj, Zniewalająca moc kultury. W: tegoż: Zniewalająca moc kultury. Artykuty i szkice z filozofii kultury, poznania i polityki. Toruń 2004, s. 181. 
Sądzimy [my - pragmatyści - przyp. M. M. S.], że poleganie na perswazji, szacunek dla poglądów kolegów, ciekawość, chęć zapoznania się z nowymi danymi i ideami są jedynymi przymiotami cechującymi naukowców. Nie sądzimy natomiast, aby poza tymi przymiotami moralnymi istniała intelektualna cnota zwana racjonalnością ${ }^{23}$.

Wydaje się, że przekonanie Rorty'ego, o tym, iż perswazja (lub też postawa $\mathrm{z}$ jednej strony wyposażona $\mathrm{w}$ perswazję, $\mathrm{z}$ drugiej - otwarta na wszystkie poglądy) jest moralna, to założenie zbyt idealistyczne. Bezpieczniejsze byłoby stwierdzenie, iż „bywa czasami moralna”. Związki Rorty'ego (chyba nie zawsze uświadamiane?) z retoryką sofistyczną ujawniają się często i nadzwyczaj wyraźnie. Amerykański pragmatysta uważa, na przykład, że:

warto unikać pojęcia „lepszej” argumentacji i zastępować je pojęciem „argumentacji, która jest najskuteczniejsza wobec danego audytorium". Sądzę - mówi Rorty - że łatwiej jest zaprzestać stosowania pojęcia uniwersalnej prawomocności (validity) i zamiast tego mówić o tym, co może być uzasadnione dla danego audytorium, porzucając heurystyczną fikcję uniwersalnego audytorium, audytorium idealnego. Oczywiście, pewne audytoria są moralnie i politycznie lepsze niż inne. Nie sądzę jednak, aby istniały argumenty, które same w sobie byłyby lepsze lub gorsze, niezależnie od rodzaju audytorium, do którego są adresowane ${ }^{24}$.

W powyższym cytacie Rorty odwołuje się do kilku powszechnie znanych i stosowanych (nie zawsze o sofistycznej proweniencji, choć zawsze przez sofistów wykorzystywanych) „prawd retorycznych”. Zacznijmy od końca. Nie ma argumentów "samych w sobie lepszych lub gorszych", "nie ma też prawdziwych ani fałszywych wartości: są tylko przyjęte lub odrzucone" - podobnie jak retoryka sama w sobie nie jest ani zła, ani dobra. Przypomnijmy tu tylko podstawowe fakty z historii retoryki. Już Gorgiasz w dialogu Platońskim zauważa, że retoryka może być używana zarówno „źle", jak i „dobrze”:

należy się posługiwać retoryką w sposób sprawiedliwy, jak sztuką walki. Moim zdaniem [- mówi Gorgiasz przyp. M. M. S.], jeśli ktoś zostawszy mówcą zaczyna potem nieuczciwie posługiwać się tą władzą i sztuką, nie powinniśmy za to winić jego nauczyciela i wypędzać go z państwa. Uczył on bowiem tej sztuki, by się nią uczciwie posługiwać, tamten zaś używa jej niegodnie. Ten zatem, kto z niej czyni zły użytek zasługuje na potępienie, wygnanie i śmierć, nie jego nauczyciel [Gorgiasz $457 \mathrm{~b}]^{25}$.

${ }^{23}$ R. Rorty, Nauka jako solidarność. Przeł. A. Chmielecki. „Literatura na Świecie” 1991, nr 5, s. 209.

${ }^{24}$ R. Rorty, Pojęcie racjonalności. W: Habermas, Rorty, Kołakowski, Stan filozofii wspótczesnej. Przekład i opracowanie J. Niżnik. Warszawa 1996, s. 119.

25 Platon, Gorgiasz. Menon. Przełożył, wstępem i komentarzem opatrzył P. Siwek. Warszawa 1991, s. 23. Tę wypowiedź Gorgiasza jako bohatera dialogu następująco komentuje Zbigniew Nerczuk (Sztuka a prawda. Problem sztuki $w$ dyskusji między Gorgiaszem a Platonem. Wrocław 2002, s. 145): „W przekonaniu sofisty sama retoryka jako sztuka nie może być „winna” (aitia) w sytuacji, gdy czyni

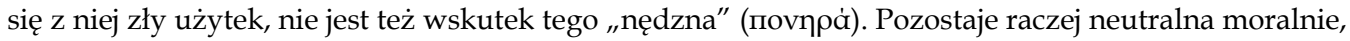


Otwarte pozostaje pytanie, czy etyka sytuacyjna, kairotyczna, propagowana m.in. przez sofistów, ale i przez współczesnych badaczy, może zagwarantować sprawiedliwe posługiwanie się retoryką. A może raczej to właśnie ta zmienność i chwilowość czyniła/czyni sztukę oratorów szczególnie podatną na wszelkie nadużycia i manipulacje?

Do poglądów Gorgiasza nawiązywał Olimpiodor ${ }^{26}$, również Izokrates uważał, że nie należy krytykować zasad retoryki, lecz tych, którzy posługują się wymową w sposób niemoralny. Wykazywał, że tak samo można oskarżać bogactwo, siłę i odwagę, a byłoby przecież rzeczą niewłaściwą przenosić zło ludzi na rzeczy27. W obronie „neutralności” zasad retoryki występował także św. Augustyn ${ }^{28}$, a podobne uwagi powtarzane były w wielu podręcznikach retoryki aż do połowy XIX wieku. Upadek retoryki przyniósł także jej krytykę jako jednego z „narzędzi” służących do utrwalania starego porządku, a stąd już tylko krok - co skrzętnie wykorzystano w XX wieku - do oskarżenia jej o brak neutralności, czyli o silne zideologizowanie. A przecież - potwierdzają to przytoczone wyżej opinie - wszystko zależy od użytkownika-mówcy. Jest on jednak tylko jednym z elementów sytuacji komunikacyjnej. Pozostałe dwa to: komunikat i odbiorcy. Rorty jest przekonany, że nie ma „uniwersalnego audytorium”. Dobrze wiedzieli o tym sofiści, dlatego szczególnie zalecali kategorię kaıpós (dosłownie: „odpowiedni moment”) - oznaczającą okazję, która determinuje określone postępowanie mówcy. Aby być skutecznym, musi on dostosować swoją argumentację do konkretnego audytorium.

Opisana przez Rorty'ego psychologiczno-sytuacyjna koncepcja argumentacji retorycznej wskazuje na dialogiczną relację między mówcą i słuchaczami. Wymaga to od mówcy włączenia do własnego procesu inwencyjnego sposobu myślenia publiczności, a nie jedynie przystosowania dyskursu do konkretnego odbiorcy. Słuchacze stają się rzeczywistymi współautorami wywodu, a nie wyłącznie „in-

a winą obarczeni są ci, którzy wykorzystują sztukę w niegodziwych celach. Podobnie jak w Pochwale Heleny, Gorgiasz opowiada się w dialogu za oddzieleniem sfery technicznej od sfery moralności. Sztuka stoi zatem z dala od moralności, moralni lub niemoralni są ludzie, którzy się nią posługują. W rezultacie znajomość reguł sztuki nie ma żadnego bezpośredniego i koniecznego wpływu na aspekt etyczny działania".

${ }^{26}$ Autor słynnego powiedzenia: „Trzeba zatem wiedzieć, że tak jak miecz nie jest sam w sobie ani dobrem, ani złem, w ten sam sposób retoryka sama dla siebie nie jest dobrem, ale dla używającego jej staje się dobrem". Cytujemy za: K. Tuszyńska-Maciejewska, Filozofia w retoryce Gorgiasza z Leontinoj. Poznań 1987, s. 114.

27 Zob. J. Macjon, Ślady sofistycznej teorii względności dobra w pismach Izokratesa. "Meander” 1980, z. 3, s. 102. Zob. Idem, Sofistyczna geneza doktryny etyczno - pedagogicznej Izokratesa. "Meander" XXXVIII, 1983, z. 9.

28 „Istnieją [...] pewne zasady dotyczące przedmiotu [...], zwanego wymową. One same są prawdziwe, choć za ich pomocą można przekonywać i o rzeczach fałszywych. Ponieważ jednak stosuje się je do prawdziwych, winę ponosi nie sam przedmiot, ale przewrotność tych, którzy źle się nim posługują" [De doctrina christiana II, XXXVI, 54]. 
nymi", których mówca ledwie zauważa. W takim przypadku orator w swojej praktyce musi stosować "kairotyczną inwencję", czyli być szczególnie „czujny” na konkretne okoliczności danej retorycznej sytuacji ${ }^{29}$.

Stanley Fish - drugi z czołowych amerykańskich neopragmatystów - następująco definiuje retorykę: „Retoryka jest przecież inną nazwą antyfundamentalizmu i można bez wielkiej przesady stwierdzić, że nowoczesny antyfundamentalizm to stara sofistyka w wersji analitycznej" 30 . Amerykański literaturoznawca przekonuje nas, że:

Kłótnia [...] pomiędzy filozofią a retoryką przetrwała wszystkie istotne przemiany, jakie zaszły w historii myśli zachodniej, stale stawiając nas w obliczu wyboru (typu: albo - albo) pomiędzy prostą, nagą prawdą wprost przedstawianą, i potężnym, lecz zdradliwym odwoływaniem się do „pięknego języka”, języka, który przekracza granice reprezentacji i zastępuje swymi własnymi formami formy rzeczywistości ${ }^{31}$.

Andrzej Szahaj, interpretując poglądy Fisha na temat tradycji filozoficznej, pisze m.in.:

Uważa [Fish - przyp. M. M. S.], iż jest w niej [tradycji filozoficznej - przyp. M. M. S.] obecny od zawsze element retoryki, więcej - że każda jej forma jest de facto przede wszystkim retoryką. Te orientacje filozoficzne, które $\mathrm{z}$ ową retoryką walczą $\mathrm{w}$ imię uzyskania jakiegoś pozasytuacyjnego wglądu w istotę rzeczy, Prawdy pozaczasowej itd., są jedynie nad wyraz skutecznymi mechanizmami perswazji retorycznej, perswazji dokonanej $\mathrm{w}$ imię jakichś swoich lokalnych, stronniczych przekonań. W sławnym sporze Platona z sofistami Fish staje więc po stronie sofistów, pokazując, że każda forma platonizmu to jedynie sofistyka w przebraniu ${ }^{32}$.

Jeśli w sporze między Platonem a sofistami opowiemy się - a tak czyni spora część przedstawicieli ponowoczesności - za tymi drugimi, „Jeśli [...] zgoda ta nastąpi, czeka nas wielka praca przepisania całej historii filozofii europejskiej, historii całej kultury europejskiej pod kątem ziemskiej roli i źródeł (kulturowych, politycz-

${ }^{29}$ Zob. M. Skwara, O dowodzeniu retorycznym w polskich drukowanych oracjach pogrzebowych XVII wieku. Szczecin 1999, s. 154.

${ }^{30}$ S. Fish, Antyfundamentalizm, nadzieja na teorię a nauczanie kompozycji literackiej. Przeł. M. Glasenapp-Konkol. W: Idem, Interpretacja, retoryka, polityka. Eseje wybrane, s. 368. Komentując ten fragment wypowiedzi Fisha, Andrzej Szahaj (Granice anarchizmu interpretacyjnego. W tegoż: Zniewalajaca moc kultury, s. 118) napisał m.in.: „Przyjmując to dictum powiedziałbym [...], że interpretacja jest królestwem retoryki, w którym zamiast Prawdy czy Obiektywności lepiej mówić o sile perswazyjności, świeżości metafor i etycznych intencjach (jeśli na przykład skłonny byłbym powiedzieć, że nie wszystko wolno $\mathrm{w}$ praktyce interpretacyjnej, to wynika to $\mathrm{w}$ moim przypadku także $\mathrm{z}$ poczucia więzi z tą wspólnotą interpretacyjną, która uważa, że istnieją teksty kultury, z którymi należy obchodzić się z wyjątkowym szacunkiem, choćby po to, aby nie ranić innych)".

${ }^{31}$ S. Fish, Retoryka, op. cit., s. 430-431.

32 A. Szahaj, Zniewalajaca moc kultury, op. cit., s. 181, 
nych, ideologicznych) jej najważniejszych rozstrzygnięć" 33 . Nie ma jednak żadnej gwarancji, że taka działalność będzie „lepsza” oprócz - a to pewien idealistyczny paradoks $\mathrm{w}$ gruntownym zakwestionowaniu idealizmu - etyki przepisujących.

Spójrzmy, jak Fish uzasadnia swoje stanowisko wobec kategorii dobra i prawdy, charakterystycznie wspierając swoje wywody odwołaniem do dwóch sentencji przypisywanych Protagorasowi. Pierwsza z nich głosi, że "O bogach nie mogę wiedzieć ani czy istnieją, ani czy nie istnieją, ani też jaka jest ich istota i jak się pojawia"; z tego twierdzenia Protagoras wywodzi kolejne: ponieważ brak jest boskiego przewodnictwa, „miarą wszystkich rzeczy jest człowiek”, ale

Nie znaczy to, że rezygnuje się z kategorii prawdy i dobra, lecz że w odmiennych kontekstach będą one spełniane odmiennie i że nie istnieje żaden kontekst nadrzędny (ponieważ ten mógłby być zajmowany jedynie przez niedostępnych bogów), z którego punktu widzenia różnice owe mogłyby być stwierdzone i osądzone" ${ }^{\prime 34}$.

Rezultatem przyjęcia przez Fisha twierdzeń sofistycznych jest (podobnie jak u Rorty'ego) przesunięcie retoryki „z pogardzanych peryferii do koniecznego centrum" ${ }^{35}$. Jeśli bowiem najwyższą prawdą dla każdego poszczególnego człowieka jest to, w co wierzy, że jest prawdą, to umiejętność - retoryka - która tworzy przekonania i dzięki temu ustanawia, co w konkretnym czasie i miejscu jest prawdą, jest umiejętnością podstawową dla budowania i podtrzymywania cywilizowanego społeczeństwa. Za tak sformułowanymi poglądami kryje się stanowisko, które filozofowie określają jako „fallibilizm” - „poczucie, że nasza wiedza jest niedoskonała, prowizoryczna, podlega rewizji w obliczu nowych dowodów"36. Jednocześnie neopragmatycy wydają się głosić poglądy antyrealistyczne. Przyczyny takiego stanowiska stara się ujawnić John R. Searle:

Motywacją do zaprzeczania realizmowi jest [...] rodzaj żądzy władzy, która objawia się na wiele sposobów. Na uniwersytetach, szczególnie w dziedzinach humanistycznych, przyjmuje się, że nie istnieje świat realny, a więc nauki ścisłe mają takie same podstawy jak humanistyka. Obie te gałęzie wiedzy zajmować by się miały konstruktami społecznymi, a nie autonomiczną rzeczywistością. $Z$ takiego założenia łatwo wyprowadza się różne formy postmodernizmu, dekonstrukcjonizmu i tak dalej, wyzwoliwszy się zupełnie z dokuczliwych więzów i ograniczeń, jakie tworzy konieczność konfrontacji z realnym światem. Jeśli świat realny jest tylko wynalazkiem - konstruktem społecznym przeznaczonym do tego, aby ciemiężyć niższe warstwy społeczne - pozbądźmy się realnego świata i stwórzmy świat taki, jaki chcemy. Jest to [...] rzeczywista siła psychologiczna, na której opiera się antyrealizm końca dwudziestego wieku ${ }^{37}$.

\footnotetext{
${ }^{33}$ A. Szahaj, Ponowoczesny liberalizm Johna Graya. W: Idem, Zniewalająca moc kultury, op. cit., s. 235.

34 S. Fish, Retoryka, op. cit., s. 433.

35 Ibidem.

${ }^{36}$ Zob. K. A. Appiah, Kosmopolityzm. Etyka w świecie obcych. Przeł. J. Klimczyk. Warszawa 2008, s. 170.

37 J. R. Searle, Umyst, język, społeczeństwo. Filozofia i rzeczywistość. Przeł. D. Cieśla. Warszawa 1999,
} s. 41. 
Z powodu braku prawdy absolutnej, retoryka jest umiejętnością, której ucząc, sofiści przekonywali, że „jedyna rzecz, która ma znaczenie, to to, jak dbać o swoje własne sprawy i interes państwa" 38 . Tu docieramy do argumentu, który zawsze bywa przytaczany $\mathrm{w}$ kolejnych polemikach z sofistyczną retoryką, a mianowicie do jej specyficznych związków i powiązań z polityką. Retoryka w świecie ponowoczesnym - o czym nie zawsze się mówi lub chce się pamiętać - to doskonałe narzędzie utrzymywania ładu, tym doskonalsze, że nie odwołuje się do przymu$\mathrm{su}$, a stara się przekonywać.

Roger Kimball, krytyk neopragmatyzmu Stanleya Fisha, szósty rozdział swojej książki zatytułowany „Nowa sofistyka” 39 , rozpoczyna od przytoczenia w charakterze motta wypowiedzi sofisty Trazymacha z Państwa Platona: „to, co sprawiedliwe, to nic innego, jak tylko to, co leży w interesie mocniejszego (338 C)" 40 . Kimball potępia Fisha za celową próbę zastąpienia, w szeroko rozumianym życiu społecznym, rozumu przez retorykę, prawdy przez perswazję i skuteczność, przy użyciu prostego wybiegu, polegającego na zaprzeczeniu, że jest między tymi pojęciami jakakolwiek esencjonalna różnica. Szczególne znaczenie perswazji jako narzędzia, które wystarcza do poznania prawdy, następująco opisuje Rorty:

Wszystko, czego potrzeba, by umożliwić komunikację i perswazję, a tym samym i poznanie, to językowa kompetencja niezbędna do tego by przechodzić z poziomu na poziom. Chcąc wyjaśnić proces nabywania tej kompetencji, nie musimy postulować istnienia przedmiotu - samego tekstu, jego prawdziwego znaczenia, bądź grudki czy rzeczywistej jej esencji - uobecniającego się w świadomości na każdym poziomie. Niezbędna jest jedynie możliwość osiągnięcia porozumienia wokół tego, o czym mówimy ${ }^{41}$.

Kimbell kategorycznie potępia postawy neopragmatyczne reprezentowane przez profesorów wyższych uczelni, uważając, iż jest to odrzucenie klasycznych ideałów, prowadzące do skorumpowania uczelni przez sofistów, którzy w swej działalności naukowej i pedagogicznej porzucili najbardziej elementarne prawdy.

Spór o kształt i charakter uniwersytetu w cywilizacji zachodniej jest dziś sporem między dwiema ideami, koncepcjami: $z$ jednej strony - starsza, zbudowana na modelu Humboldtiańskim, odwołująca się do prawdy, etyki, autorytetu i autonomii; z drugiej - nowsza, odwołująca się do amerykańskiej idei „u n i w e r s y t e t u

38 W. K. Guthrie, The Sophists. Cambridge 1971, s. 186, cytujemy za: S. Fish, Retoryka, op. cit., s. 434.

${ }^{39}$ Zob. R. Kimball, Tenured Radicals. How Politics Has Corrupted Our Higher Education. New York 1990, s. 142-165. Zob. M. Skwara, Między sofistyka a neopragmatyzmem, czyli o "etyce sytuacyjnej”, s. 66 i nast.

40 Platon, Państwo. Przełożył, wstępem, objaśnieniami i ilustracjami opatrzył W. Witwicki. T. 1. Warszawa 1991, s. 41.

${ }^{41}$ R. Rorty, Obiektywność, relatywizm i prawda. Pisma filozoficzne. T. 1. Przeł. J. Margański. Warszawa 1999, s. 134. 
przedsiębiorczego opartego na mechanizmie rynkowym"42, a więc przede wszystkim wyposażającego studentów w umiejętności skutecznej komunikacji. To ta właśnie umiejętność budzi wiele zastrzeżeń, szczególnie wtedy, gdy ma być jedyną umiejętnością, jaką zdobywają studenci. Stanowisko takie krytykuje m.in. Eric W. Rothenbuhler:

Jeżeli nauczymy studentów wymogów skutecznej komunikacji, wyruszą oni w świat jako praktycy komunikacji, dążąc do osiągnięcia właśnie tego - skuteczności. Ich celem, ich kryterium sukcesu stanie się wpływ. [...] O ileż bardziej warto - poprzez proces nauczania i badania - powoływać do życia świat [...], w którym komunikację ceni się za jej cudowną i magiczną moc, którą należy wykorzystywać z zachowaniem wszelkiej ostrożności, tylko dla realizacji najlepszych celów. To jest właśnie moralny wymiar komunikacji $[\ldots]$; kto bada jedynie skutki zapomina o tym ${ }^{43}$.

Dopowiedzmy: moralny wymiar komunikacji może istnieć tylko wtedy, gdy biorące $\mathrm{w}$ niej udział podmioty będą się posługiwały retoryką ufundowaną na mocnej podstawie etycznej. Każdy inny rodzaj komunikacji przypomina grę, w której wygrywa ten, kto przechytrzy lub oszuka partnera dialogu. Nie zawsze zgodnie z oczekiwaniem neopragmatystów, znajduje to wyraziste odzwierciedlenie w systemie edukacji. Każdy bowiem może korzystać z retoryki uwolnionej od prawdy historycznej i etyki. Walka o treści programowe w amerykańskim szkolnictwie jest ciągle otwarta i zależy od wyników wyborów. I tak na przykład w Teksasie:

Konserwatyści pokonali liberałów w burzliwym sporze o treści nowego stanowego programu nauczania. [...] Zdominowana przez republikanów rada [ds. edukacji przyp. M.M.S.] postanowiła wyczyścić podręczniki z utrzymującej się od kilku dekad „liberalnej tendencyjności" i przedstawić Amerykanów jako naród, który ma swoje korzenie $\mathrm{w}$ biblijnych wartościach. [...] W nowym programie nauczania mają być więc promowane m.in. niskie podatki oraz gospodarka wolnorynkowa. Za istotny element demokratycznego państwa uznano również prawo do noszenia broni. Uczniowie mają się też mniej uczyć się o prezydencie Thomasie Jeffersonie, który propagował rozdział Kościoła od państwa, a więcej o republikańskich politykach. Podręczniki mniej uwagi poświęcać też mają ruchom praw obywatelskich czy niewolnictwu ${ }^{44}$.

Takie niespodziewane implikacje może mieć pragmatyzm, gdy myślenie jego kategoriami przejmują ci, którzy byli dotąd jego ofiarami. Zagadnienie przepisywania historii zdaje się wyjątkowo dobrze obrazować zabiegi sofistyczne, z któ-

${ }^{42} \mathrm{~K}$. Biały, Czy nowy "porządek dyskursu”? - na przykładzie jezyka szkolnictwa wyższego w Polsce. „Tekstualia” 2007, nr 4, s. 40.

${ }^{43}$ E. W. Rothenbuhler, Komunikacja rytualna. Od rozmowy codziennej do ceremonii medialnej. Przekład i redakcja J. Barański. Kraków 2003, s. 156-157.

${ }^{44}$ J. Przybylski, Rewolucja oświatowa w Teksasie. „Rzeczpospolita” 2010, nr 118, s. 13. 
rymi mamy do czynienia wszędzie tam, gdzie ścierają się ideologie, nas szczególnie interesuje kontekst postkolonialny. Przypomnimy więc najpierw tradycje stalinowskie, z reguły, choć nie zawsze i nie przez wszystkich, kwalifikowane dziś jako złe, by przejść do zjawisk współczesnych, posługujących się podobnymi chwytami sofistycznymi, z reguły, najczęściej przez samych twórców, kwalifikowanych jako dobre i nowoczesne.

Podstawowy zabieg manipulowania historią polegał na tym, że komuniści niezależnie od czasu i miejsca - próbowali udowodnić, iż prawdziwa historia zaczyna się z chwilą ich dojścia do władzy. Stefan Kisielewski słusznie zauważył, iż „dla komunistów historia zaczyna się od nich samych, z tym, że i swojej krótkiej historii też nie szanują, naginając ją tak i siak według meandrów taktyki politycznej"45. To ostatnie zjawisko przekracza oczywiście granice epok, państw, czy nawet obozów politycznych. Odwołajmy się do barwnego przykładu przywoływanego m.in. przez Slavoja Žižka:

Weźmy pewną charakterystyczną cechę oficjalnego dyskursu współczesnej Korei Północnej, jedynego kraju, który ciągle praktykuje szlachetną stalinowską sztukę przepisywania historii. Obecny władca Kim Dzong Il, urodził się w 1945 roku, kiedy jego ojciec był na zesłaniu w syberyjskiej wiosce. Gdy pod koniec lat pięćdziesiątych stosunki między Koreą Północną i ZSRR pogorszyły się, dystans wobec Związku Radzieckiego zaznaczył się w zmianie miejsca urodzenia: nagle, bez żadnego wyjaśnienia wszystkie książki zostały przepisane i zaczęto utrzymywać, że Kim Dzong IL urodził się na szczycie najwyższej góry w Korei. [...]. „Nie chodzi o miejsce urodzenia, lecz o sygnał, że stosunki z ZSRR uległy zmianie!"46

W związku z przywołaną tu manipulacją, warto przytoczyć pełną troski opinię Paula Connertona: „W ustrojach totalitarnych przeraża nas nie tylko pogwałcenie ludzkiej godności, lecz także strach, że być może nie pozostanie już nikt, kto mógłby jeszcze kiedyś dać świadectwo o przeszłości" 47 . W przypadku państw, w których komunistyczne niszczenie pamięci trwało kilkadziesiąt lat - a do państw takich należy między innymi Polska - problem polega nie tylko na tym, że nie pozostał już nikt, kto mógłby dać świadectwo, ale i na tym, że pojawiają się próby zdezawuowania wszelkich świadectw, i kolejne projekty pisania historii od nowa.

Maria Dąbrowska następująco opisała proces fałszowania historii w czasach stalinowskich:

W naszej polskiej wersji naśladowania Rosji (procesy obecne, w których przeciwnik polityczny jest nieuchronnie łotrem, szpiegiem i zdrajcą) idzie o wytępienie całego tak

45 S. Kisielewski, Dzienniki. Warszawa 1996, s. 502.

${ }^{46}$ S. Žižek, Lacrimae rerum. Kieślowski, Hitchcock, Tarkowski, Lynch. Przekład zbiorowy. Przedmową opatrzył K. Mikurda. Kraków 2007, s. 147-148.

${ }^{47}$ P. Connerton, Jak społeczeństwa pamiętają. Przekład i wstęp M. Napiórkowski. Warszawa 2012, s. $52-53$. 
straszliwego wysiłku walki narodu z Niemcami, i wykazanie, że wyłącznie komuniści podjęli i przeprowadzili walkę z Niemcami. Ludzie Rosji nie spoczną, póki nie wykażą tego choćby kosztem wymazania całych połaci faktów z historii. Nie fakty, tylko komentarze do faktów tworzą historię. Jeśli fakt nie pasuje do komentarza - won z faktem. Pod tym względem marksiści pozostali wierni Heglowi, z którego się i w innych rzeczach wywodząa ${ }^{48}$

W przytoczonej opinii - przypomnijmy, zapisanej w 1948 roku ${ }^{49}$ - przynajmniej jedno zdanie brzmi bardzo współcześnie: „Nie fakty, tylko komentarze do faktów tworzą historię". Wielu przedstawicieli trzeciej sofistyki podpisałoby się pod tym zdaniem. Maria Dąbrowska doskonale dostrzegła nici łączące rozmaitych manipulatorów i opisywaczy procesów historycznych i, co wydaje się tu szczególnie ważne, zwróciła uwagę także na to, jakie niebezpieczeństwa wiążą się z tego rodzaju działalnością. Chodzi przede wszystkim o zanegowanie jakiejkolwiek indywidualnej czy zbiorowej odpowiedzialności za czyny z przeszłości. Leopold Tyrmand wyjaśniał: „Skoro historia reguluje się samoczynnie, jak najnowszy zegarek szwajcarski nie wymagający nakręcania, wszystko jest więc zdeterminowane przez nieodwracalny proces, a pojęcie takie jak moralna odpowiedzialność - jednostkowa czy społeczna - nadają się na złom"50. Tyrmand już w latach 60. mówił też o „neosofistyce jako odrodzonej gałęzi filozofii”:

Dziś na Zachodzie w warunkach wolności badań liczni romantycy socjologii, sentymentalni political scientists i spekulatywni psycholodzy grzebią się gorliwie w nieskończoności wersji o ideowych egzystencjach byłych stalinowców. Faktem jest, że ci ostatni wyprodukowali gigantyczną literaturę o swych wiarach i bólach pełną tak przepastnych eufemizmów, że można już mówić o neosofistyce jako o odrodzonej gałęzi filozofii ${ }^{51}$.

Czy wymienione zjawiska zamykają się w jednym okresie, komunistycznych manipulacji związanych z określoną ideologią i systemem politycznym? Nie tylko zasady trzeciej sofistyki, absorbowane i przystosowane do nowych potrzeb, ale i refleksje takie jak poniższa, wyrażona przez Piotra Kozaka:

\footnotetext{
${ }^{48}$ M. Dąbrowska, Dzienniki powojenne 1945-1949. Wybór, wstęp i przypisy T. Drewnowski. Warszawa 1996, s. 206.

${ }^{49}$ Co nie znaczy, że Maria Dąbrowska zaprzestała później odnotowywania faktów dotyczących zamazywania historii, zacytujmy dzienniki z kolejnej dekady: „»Po prostu “ z 12 V [1957] zademonstrowało fotokopię z »Materiałów do dziejów postępowej publicystyki« wydanych przez IBL pod redakcją Ewy Korzeniewskiej. Pokazano tam dwutygodnik wileński »Karta « z 1 VI 36 roku ze spisem współpracowników. Red. IBL-u sfałszowała ten spis w stylu »no facts« Orwella - wymazując z niego nazwisko Miłosza. Druga fotokopia »Po prostu« jest reprodukcją oryginału i zawiera nazwisko Miłosza. Kiedy skończą się takie kompromitacje?”. M. Dąbrowska, Dzienniki powojenne 1955-1959. Wybór, wstęp i przypisy T. Drewnowski. Warszawa 1996, s. 234.

${ }^{50}$ L. Tyrmand, Cywilizacja komunizmu. Londyn 1992, s. 116.

51 Ibidem, s. 257.
} 
Po trwającym ponad półwieku procesie destalinizacji wydaje się, że ostatecznie wyzwoliliśmy się z wszelkich z nim związków. Niesłusznie. Wystarczy rozejrzeć się wokół siebie, popatrzeć na nasze miasta - i w Polsce, i w całej Europie ŚrodkowoWschodniej. Większość pomników zdołaliśmy wysadzić. Zmieniliśmy nazwy ulic. Ale te ulice i stojące przy nich domy pozostały. Chcemy tego czy nie, jesteśmy i będziemy dziećmi Stalina ....52

wydają się wołać o ostrożność w odsyłaniu do przeszłości zjawisk kształtowania historii wedle bieżących potrzeb ideologicznych. Obok historycznego pojęcia "stalinizmu” i właściwych mu praktyk, wskazuje się współcześnie na nurty „neostalinizmu". John Radziłowski określenie „dyskurs neostalinowski” odnosi do szkoły polskich studiów historycznych, która powstała i rozwinęła się w ciągu ostatniego dziesięciolecia w USA:

Celem neostalinizmu jest całościowe przepisanie od nowa historii Polski, a następnie całkowita zmiana polskiej kultury i tożsamości. Praktycy neostalinizmu dążą do stworzenia nowej „świeckiej” polskiej tożsamości, którą uważają za bardziej oświeconą, postępową i ogólnie górującą nad wszystkim, co przeszłe - w sumie chodzi więc o nowego, postmodernistycznego Polaka ${ }^{53}$.

Radziłowski uważa, iż rozprzestrzenienie się neostalinizmu można także interpretować jako odpowiedź na zmiany, jakie nastąpiły w polskim życiu intelektualnym po 1989 roku:

Neostalinizm można postrzegać [...] jako ofensywę stanowiącą odpowiedź na zamieszanie panujące w polskim życiu intelektualnym, kulturowym i społecznym po $1989 \mathrm{r}$. W związku z tym, warunki debaty i sposób patrzenia na nowożytną historię Polski były lub wydawały się być uchwytne dla każdego, kto tylko pragnął uczestniczyć w walce o "rząd dusz". W sferach polityki i ekonomii nowe polskie elity otwarcie mówiły o "dogonieniu” Europy, a w wielu wypadkach usiłowały wyzbyć się zewnętrznych znamion tożsamości polskiej na rzecz „europejskiej”. Duch czasów sprzyjał więc polskiej wersji „długiego marszu poprzez instytucje”, wylansowanej przez takich marksistowskich ideologów jak Antonio Gramsci, a następnie przez tzw. szkołę frankfurcką, która przeniosła marksizm ekonomiczny na płaszczyznę kulturową $a^{54}$.

Taki sposób rozumowania oznacza, że stosunkowo nieliczna elita - to właśnie wśród jej członków upatrywali swoje miejsce zarówno stalinowcy, jak i współcześnie neostalinowcy - jest w stanie zmienić społeczeństwo i jego historię, tradycję,

52 P. Kozak, Stowo wstępne. W: B. Groys, Stalin jako totalne dzieło sztuki. Przeł. P. Kozak. Warszawa 2010, s. 11.

53 J. Radziłowski, Dyskurs neostalinowski w polskich studiach historycznych w Stanach Zjednoczonych. W: Złote serca czy złote żniwa? Studia nad wojennymi losami Polaków i Żydów. Redakcja naukowa M. J. Chodakiewicz, W. J. Muszyński. Warszawa 2011, s. 260.

54 J. Radziłowski, ibidem, s. 267. 
przekonania i przyzwyczajenia. Tak budowany model edukacji ma, oczywiście, szerszy zasięg niż amerykańska szkoła historyków - skupiona przede wszystkim na przepisywaniu Holocaustu - ma też i krajowy wymiar. Po obchodach rocznicy zbrodni w Jedwabnem w dyskusji redakcyjnej Marcin Król napisał m.in.:

Jakakolwiek zatem mogłaby zaistnieć wspólnota określana mianem „polskości” czy "ojczyzny", to będzie musiała być zbudowana niemal na nowo. Odbudowana na gruzach. I nic w tej odbudowie już nie pomogą te składniki pamięci zbiorowej i wyobraźni, które dotychczas dobrze funkcjonowały, czyli romantyzm, "przerabianie zjadaczy chleba w anioły”, Mochnackiego "brukowanie Polski szlacheckimi herbami”, wspomnienia pokolenia naszych rodziców i dziadków z czasów AK i cały ten typ tradycji55.

Korzenie metaforyki budowlanej, którą tak chętnie posługuje się Marcin Król, tkwią $\mathrm{w}$ czasach stalinowskich. To wtedy wymyślono projekt odbudowywania/budowania nowej Polski, nowego polskiego społeczeństwa, a w pierwszym szeregu walki o nową Polskę byli, oczywiście, "inżynierowie dusz"56. W podsumowaniu wywodu Króla czytamy m.in.: „dzieje honoru w Polsce skończyły się. Może tak musiało być, może rewolucja demokratyczna musiała do tego doprowadzić, ale co dalej? Nie wiem. Chyba tylko wielki, ale stały, codzienny wysiłek reedukacji i resocjalizacji na skalę całego społeczeństwa, łącznie z nami, bo od siebie trzeba zaczynać" 57 . Gdyby w wypowiedzi tej zastąpić „rewolucję demokratyczną" "rewolucją socjalistyczną", cytat ten doskonale mieściłby się w publicystyce stalinowskiej lat 50.: ten sam fatalizm historii i to samo żądanie powszechnej edukacji (oraz resocjalizacji - resocjalizuje się wszak przestępców, którymi w dyskursie Króla zostali wszyscy Polacy). To samo jest także odrzucenie pewnych okresów (faktów) kulturowych i historycznych, a uprzywilejowanie innych. Wreszcie - te same zabiegi retoryczne służą podobnemu celowi - formowaniu nowego, w założeniu, mówcy, lepszego człowieka, tym razem jednak nie „człowieka socjalistycznego", ale „dobrego Europejczyka" 58 .

Można, oczywiście, powiedzieć, że dyskurs publicystyczny zawsze charakteryzuje się uproszczeniami, a zaobserwować to można i na wielu innych przykładach $^{59}$. Nie wydaje się też, by jego uczestnicy zdawali sobie sprawę z rodowodu

${ }^{55}$ Akt skruchy $i$ co dalej? Rozmowa w redakcji „Res Publiki Nowej”. W: Przeciw antysemityzmowi 1936-2009. T. 3. Wybór, wstęp i opracowanie A. Michnik. Kraków 2010, s. 611.

56 Zob. M. Borwicz, Inżynierowie dusz. "Zeszyty Historyczne” 1963, nr 3, s. 121-163.

57 Akt skruchy i co dalej?, op. cit., s. 612.

${ }^{58}$ Daje tu o sobie znać mechanizm "hegemona zastępczego" opisany przez Ewę Thompson, zob. E. Thompson, op. cit., s. 116-125.

59 Andrzej Nowak przypomniał opinię Jacka Żakowskiego o rocznicy wybuchu powstania styczniowego: „Publicysta Jacek Żakowski [...] na falach eteru wyraził oburzenie, iż Senat nie był tak przezorny jak Sejm i jednak powstanie styczniowe uznał za godne uznania specjalnymi obchodami w 150 . Rocznicę. »Bym się zawahał, czy akurat te tradycje, bezmyślnej, beznadziejnej, bezsensownej walki, 
swego myślenia, a to już, być może, znak nie tylko braku wiedzy (o którą trudno posądzać profesorów uniwersytetów w roli publicystów), ale i tkwienia w pewnym sposobie myślenia, którego wspólnym mianownikiem jest właśnie sofistyka, mająca na celu uzyskanie doraźnych korzyści ideologicznych.

Pokażmy to zjawisko na przykładzie gry słowami "patriotyzm” i „faszyzm”. Oba były mocno osadzone w tradycji komunistycznej i późniejszej stalinowskiej, oba mają bogatą współczesną reprezentację w polskim dyskursie ponowoczesnym. Marci Shore opisała taką oto rozmowę między Stalinem i Wandą Wasilewską: "Stalin sam zaproponował nazwę Związek Patriotów Polskich. Wasilewska nie była z niej zadowolona. Powiedziała Stalinowi, że w Polsce słowo "patriota” skompromitowało się i jest powszechnie kojarzone $\mathrm{z}$ nacjonalizmem. Na to Stalin zapewnił ją, że każdemu słowu można nadać nową treść"60. Jesteśmy w samym centrum sofistyki w wydaniu stalinowskim. Zgodnie $\mathrm{z}$ nią, każdemu słowu można nadać dowolną treść, odpowiadającą ideologii mówcy. Fakt skompromitowania słowa „patriota” w środowiskach komunistycznych potwierdza np. Paweł Śpiewak. Pisząc o członkach KPP zauważa, iż „,[..] komunistom słowo patriotyzm dziwnie się mieszało $\mathrm{z}$ potępianym nacjonalizmem [...]"61. Nie był to jednak dziwny przypadek, jak sugeruje zastosowaną stylistyką Śpiewak, ale z rozmysłem zaplanowana desemantyzacja, otwierająca drogę do internacjonalizmu, któremu na przeszkodzie, choć z innych powodów, stały i patriotyzm, i nacjonalizm. W publicystycznym dyskursie ponowoczesnym obserwujemy kolejną odsłonę zabiegów na pojęciu patriotyzmu, grającą na podobnej nucie „skompromitowania". Magdalena Środa, pisze, iż: "Słowo "patriotyzm « kojarzy się z agresją lub ze śmiertelną nudą. Największymi »hard « patriotami są w Polsce kibice klubów piłkarskich"62. Można powiedzieć, że autorce „dziwnie miesza się" patriotyzm $\mathrm{z}$ agresją i jednocześnie $\mathrm{z}$ nudą, i dostrzec typową dla dyskursu ponowoczesnego hybrydyzację języka (mającą zapewne podkreślić nowoczesność języka Autorki, nawet jeśli jest ona nieco na bakier z logiką używanego języka - szło chyba raczej o „hard-core" patriotów?), ale można też tu dostrzec typowe dla chwytów sofistycznych zabiegi desemantyzacyjne. Podobnym - nie jesteśmy w stanie przytoczyć

choć z całą pewnością szlachetnej, ofiarnej i patriotycznej, należy czcić właśnie teraz, kiedy wracają groźnie i bezsensownie w polskim myśleniu i polskiej polityce? Czy nadymać ten balon?«. A zatem szlachetność (niestety), ofiarność i patriotyzm znów zagrażają - jakiemuś myśleniu, nadziei i sensowi - uważa redaktor Żakowski. Podkreślmy w jego interpretacji słowo „znów”. Ono wydaje się najtrafniejsze. Tak oceny powstania, jego znaczenia w polskiej historii się zmieniają, niektóre powracają po latach, inne ze wstydem jakby zanikają". A. Nowak, Powstanie styczniowe. Obrazy polskiej pamięci. „Do Rzeczy” 2013, nr 1, s. 63.

${ }^{60}$ M. Shore, Kawior i popiót. Życie i śmierć pokolenia oczarowanych i rozczarowanych marksizmem. Przeł. M. Szuster. Warszawa 2012, s. 285.

${ }_{61}$ P. Śpiewak, Żydokomuna. Interpretacje historyczne. Warszawa 2012, s. 110.

${ }^{62}$ M. Środa, Patriotyzm jest nudny. „Wprost” 2011, nr 19, s. 40. 
wszystkich - przykładem mogłaby być wypowiedź dziennikarza TVN 24, tak oto skomentowana przez Rafała A. Ziemkiewicza, analizującego różnego rodzaju wypowiedzi medialne na temat katastrofy smoleńskiej i późniejszych, związanych z nią wydarzeń:

Od początku lat 90. nie czytałem tak wielu wyznań panicznego strachu przed Polaka$\mathrm{mi}$, ale nawet wtedy nikt nie pozwolił sobie wypowiedzieć się tak, jak uczynił to przed kamerą TVN 24 Grzegorz Miecugow: „Żałoba może obudzić demona polskiego patriotyzmu. Zacznie się walka na patriotyzmy, na to, kto jest lepszym Polakiem". [...]. Jak można, nawet wskutek lapsusu, mówić o cnocie patriotyzmu jako o „demonie"? Nawet Adam Michnik w najbardziej rozhisteryzowanych tekstach z początku III RP, w których wieszczył w Polsce Jakobinizm, wieszanie na latarniach i faszystowską dyktaturę, nie posunął się dalej niż do "demonów nacjonalizmu”. Ale słowa opiniotwórczego prezentera TVN 24 nie były pomyłką czy przejęzyczeniem skoro najwyraźniej za rzecz groźną uważa on "walkę na patriotyzmy"63.

Skojarzenie nacjonalizmu i patriotyzmu nie jest, oczywiście, przypadkowe. Jeffrey C. Alexander zauważył, że w skutek przemian ponowoczesnych:

to „nacjonalizm”, a nie tradycjonalizm, komunizm, czy: „Wschód” zaczyna stanowić najważniejsze wyzwanie dla nowo zuniwersalizowanego dyskursu dobra. „Nacjonalizm" to nazwa, którą intelektualiści i opinia publiczna coraz częściej nadają obecnie negatywnym antynomiom społeczeństwa obywatelskiego. Określenia „irracjonalny”, "spiskowy" i "represyjny" uznaje się za synonimy silnych przejawów narodowości i zrównuje z pierwotnością i niecywilizowanymi formami społecznymi. Wygodnie pomija się fakt, iż społeczeństwa obywatelskie zawsze przyjmowały postać narodową; lekceważy się też trwały nacjonalizm wielu samych ruchów demokratycznych ${ }^{64}$.

Podobną zależność między sofistyką stalinowską a współczesną dostrzec można w operowaniu pojęciem "faszyzm”, które w dyskursie publicznym zrobiło zawrotną karierę jako uniwersalna obelga obsługująca wszystkich wrogów ${ }^{65}$ - często też, ponownie nie przez przypadek, łączona $\mathrm{z}$ „patriotyzmem”. Przyjrzyjmy się źródłom. Arthur Koestler zwrócił uwagę, iż „według partii [komunistycznej -

${ }^{63}$ R. A. Ziemkiewicz, Kampania w cieniu pogardy $i$ strachu. „Rzeczpospolita” 2010, nr 94, s. 16. Praktycznie cała kampania „antysmoleńska” przybierała formę sofistycznego chwytu „argumentum ad metum (odwołanie się do strachu)", zob. B. Witkowska-Maksimczuk, op. cit., s. 171; P. H. Lewiński, Neosofistyka, op. cit., s. 172.

${ }^{64} \mathrm{~J}$. C. Alexander, Nowoczesność, antynowoczesność, ponowoczesność i neo-nowoczesność. Jak intelektualiści wyjaśniaja "nasze czasy”. W: Idem, Znaczenia spoteczne. Studia z socjologii kulturowej. Przeł. S. Burdziej, J. Gądecki. Kraków 2010, s. 184.

65 Jest to odmiana erystycznego chwytu "argumentum ad Hitlerum”, jak wyjaśnia Barbara Witkowska-Maksimczuk (op. cit., s. 159): "Chwyt ten jest odmianą [...] argumentu ad personam. Polega na dyskredytacji danej tezy tylko dlatego, że kojarzona jest z osobą lub grupą ludzi o złej reputacji”. Zob. także P. H. Lewiński, Neosofistyka, op. cit., s. 175. 
przyp. MMS], kto nie był z nami, był faszystą. Socjalistów nazywano »socjalfaszystami«, katolików »klero-faszystami«, trockistów »trockisto-faszystami« i tak dalej"66. Sięgnijmy też do paru charakterystycznych cytatów z Historii Wszechzwiązkowej Komunistycznej Partii (bolszewików):

Ukryli oni [m.in.: Zinowjew, Kamieniew, Jewdokimow - przyp. M.M.S.] swą łączność z Trockim. Ukryli, że wraz z trockistami zaprzedali się szpiegowskim wywiadom faszystowskim, ukryli swą działalność szpiegowską i szkodniczą. Zinowjewowcy ukryli przed sądem swą łączność z bucharynowcami, ukryli fakt istnienia zjednoczonej trockistowsko-bucharynowskiej bandy najemników faszyzmu ${ }^{67}$.

W innym miejscu: „Przygotowywali oni [Trocki, Zinowjew, Kamieniew przyp. MMS] porażkę ZSRR na wypadek najazdu imperialistów, stali się defetystami w stosunku do państwa robotniczo-chłopskiego, stali się nikczemnymi sługusami i agentami faszystów niemiecko-japońskich”68. I jeszcze: „W postaci trockistów, zinowjewowców zdobył sobie faszyzm wiernych sługusów, uciekających się do szpiegostwa, szkodnictwa, terroru i dywersji [...]"69.

Jednym z przykładów narastającego wraz z internacjonalnym rozwojem stalinizmu uogólnieniem pojęcia "faszyzm”, połączonego z projektem przepisywania historii, może być podręcznik pt. Literatura międzywojenna Ryszarda Matuszewskiego z roku 1953, w którym znajdował się podrozdział: Poeci w stużbie faszyzmu. Tym mianem określeni zostali: Jan Lechoń, Kazimierz Wierzyński i Józef Łobodowski ${ }^{70}$. W późniejszych redakcjach autor „przestał operować retoryką charakter-

${ }^{66}$ A. Koestler, Płomień i lód. Przygody mojego życia,. Przeł. W. Jeżewski. Warszawa 2009, s. 218. Co ciekawe, poglądy lewicowe mogą też być faszystowskie, zob. J. Goldberg, Lewicowy faszyzm. Tajemna historia amerykańskiej lewicy od Mussoliniego do polityki zmian. Wstęp L. Balcerowicz. Przeł. L. Jęczmyk, J. Lang. Poznań 2010.

${ }^{67}$ Historia Wszechzwiązkowej Komunistycznej Partii (bolszewików). Krótki kurs. Pod red. Komisji KC WKP(b). Zaaprobowany przez KC WKP(b). 1938. Warszawa 1949, s. 369. Maria Hirszowicz (Putapki zaangażowania. Intelektualiści w stużbie komunizmu. Warszawa 2001, s. 109) tak opisała manipulacje zawarte w Historii: „Jak długo fakty wymienione w Historii $W K P b$ nie podlegały weryfikacji a podlegać nie mogły w warunkach zaostrzającego się terroru - obraz tam zarysowany był jak najbardziej przekonywający. Święta księga nie tylko podawała więc prawdy, które nie podlegały żadnej dyskusji, ale odwoływała się do rozumu, do logiki dziejów, którą podważać mogli jedynie wrogowie i głupcy. Ów racjonalizm fikcji, operowanie kłamstwami powiązanymi rygorami żelaznej logiki, konstruowanie odpowiadającego władzy scenariusza przeszłości to zgoła niezwykłe osiągnięcie w zakresie propagandy".

${ }^{68}$ Historia Wszechzwiązowej Komunistycznej Partii (bolszewików). Krótki kurs, op. cit., s. 370.

${ }^{69}$ Ibidem, s. 373.

70 Zob. R. Matuszewski, Literatura międzywojenna. Warszawa 1953, s. 185-186. Pierwsze zdanie tego rozdziału jest doskonałym przykładem chwytów rodem z retoryki sofistycznej, od uogólnienia począwszy na „obiektywnym” stwierdzeniu skończywszy („błędy generalizacji”): „Wszystkie kierunki antyrealistyczne w literaturze dwudziestolecia mają charakter obiektywnie wsteczny". Rozdziałowi o poezji towarzyszy rozdział o prozie „Pisarze w służbie reakcji i faszyzmu” (s. 262-270), a tu z kolei 
rystyczną dla marksistowskiego literaturoznawstwa wczesnych lat pięćdziesiątych"71, a oznacza to $\mathrm{m}$ in., że nie znalazł się w nim wspomniany wcześniej „faszystowski" podrozdział. Wydawałoby się, że po takich doświadczeniach manipulacji ideologicznych, „faszyzm” i „faszysta” nie mogą funkcjonować we współczesnej, wolnej, nowoczesnej Polsce. Pobieżne przejrzenie publicystyki epoki dowodzi jednak czegoś wprost odwrotnego. Odwołajmy się do paru wyrazistych przekładów. Monika Olejnik na początku programu "Siódmy dzień tygodnia” w Radiu Zet (09.09.2012) stwierdziła, że nie będzie „rozmawiać o Januszu Korwin-Mikkem, bo ten jest faszystą", co zostało następująco skomentowane przez dr. hab. Rafała Pankowskiego, autora m. in. książki Neofaszyzm w Europie Zachodniej. Zarys ideologii: "»Nie dziwię się, że wielu osobom jego poglądy kojarzą się z faszyzmem «"72. Nie wchodząc w szczegóły sporu (Korwin-Mikke został nazwany faszystą za wypowiedzi głoszące, że powinniśmy oglądać zdrowych i pięknych sportowców, a nie „zboczeńców i inwalidów” występujących na paraolimpiadzie), nie można nie dostrzec sylogistycznego rozumowania, powołanego do rozstrzygnięcia sprawy autorytetu naukowego ${ }^{73}$, w którym uogólnienia i pominięcie przesłanki prowadzą słuchacza do jednego wniosku. Faszystą został nazwany również autor programów telewizyjnych Wojciech Cejrowski, czego nie mogła przegapić prawa strona sceny politycznej ${ }^{74}$ i trudno się dziwić, wszak to główną polską partię prawicową kwalifikowano do grona faszystów przy zastosowaniu np. zasady mało wyrafinowanej analogii - „ludzącego podobieństwa” marszy organizowanych przez PiS

znalazło się miejsce dla Juliusza Kadena-Bandrowskiego (zamiast zdjęcia pisarza na s. 265 zamieszczono jego karykaturę!), Ferdynanda Goetla i Zofii Kossak-Szczuckiej.

${ }^{71} \mathrm{~J}$. Smulski, „Przewietrzyć zatęchtą atmosferę uniwersytetów”. Wokót literaturoznawczej polonistyki doby stalinowskiej. Toruń 2009, s. 129.

72 http:/ / natemat.pl/30509,monika-olejnik-korwin-mikke-jest-faszysta-jego-pogladyrzeczywiscie-moga-kojarzyc-sie-z-faszyzmem (data dostępu: 12.12.2014).

${ }^{73} \mathrm{~W}$ jego wypowiedzi „poglądy” bezosobowo „kojarzą się z faszyzmem” - mimo więc iż „Korwin-Mikke nie jest faszystą $\mathrm{w}$ rozumieniu najbardziej klasycznym, historycznym tego terminu" i mimo że "faszyzm jest ideologią i ruchem politycznym, który w historii zapisał się w sposób tragiczny i nie należy tego terminu nadużywać" to „pewne elementy mentalności i ideologii faszystowskiej przetrwały do dzisiaj”; te elementy („wypowiedzi, które pochwalają dyskryminację, antysemickie poglądy, w których Korwin-Mikke notorycznie odwołuje się do stereotypu żydokomuny") zostają w całej wypowiedzi Pankowskiego przypisane Korwin-Mikkemu, wniosek więc, czy jest, czy nie jest on faszystą nie wydaje się trudny do wyciagnięcia. Zob. http://natemat.pl/30509,monika-olejnikkorwin-mikke-jest-faszysta-jego-poglady-rzeczywiscie-moga-kojarzyc-sie-z-faszyzmem (data dostępu: 12.12.2014).

74 „Czołowym »faszystą« lat 90. został [...] showman - Wojciech Cejrowski. »Brunatny Kowboj RP«" - taki tytuł dała "Gazeta Wyborcza” oskarżycielskiemu artykułowi na temat telewizyjnej audycji „WC Kwadrans”. „»On gra na faszystowskiej nucie« - mówił w tekście Krzysztof Piesiewicz, wówczas członek Rady Programowej TVP. »Tak właśnie rodzi się faszyzm i ja normalnie zaczynam się bać« - dodawał kolejny członek Rady, reżyser Piotr Łazarkiewicz". D. Kania, J. Targalski, M. Marosz, Resortowe dzieci. Media. Warszawa 2013, s. 316. 
do marszy faszystowskich czy podobieństwa hasła "Obudź się Polsko" do budzenia Niemców w latach $30^{75}$. Analogia pośród zabiegów erystycznych zawsze cieszyła się dużym powodzeniem, gdyż można ją było z powodzeniem kierować do mało wykształconej publiczności. Swoistą kulminacją efektu lustra, czyli stosowania przez przeciwników tego samego odwróconego chwytu, było opublikowanie na okładce „W Sieci” (październik 2013) zdjęcia Tomasza Lisa w mundurze hitlerowskim. Zapewne autorzy tego zabiegu woleliby nie pamiętać, że we wrześniu 1945 roku na łamach wychodzących w Moskwie "Nowych Widnokręgów" ukazała się karykatura Bora-Komorowskiego z podpisem „Panopticum hitlerowskie”:

Karykatura Mieczysława Bermana, przedstawiająca b. dowódcę AK, Naczelnego Wodza Polskich Sił Zbrojnych na Zachodzie, gen. Dyw. Tadeusza Bora-Komorowskiego z esesowską trupią czaszką na czapce jako przykład „interesującej i niebanalnej twórczości plastycznej $[\ldots]^{\prime \prime 76}$.

Szafowanie "faszyzmem"77 - podobnie jak desemantyzacja patriotyzmu, a nawet całkowite odwrócenie znaczeń, w wyniku którego słowo odbierane jako nośnik wartości pozytywnych, staje się słowem wstydliwym, czy obscenicznym - nie ogranicza się do dyskursu stricte publicystycznego, zaczęło wkraczać na teren rozważań dotyczących literatury, zwykle zarezerwowany dla znawców. I w roli znawcy wystąpiła Agata Bielik-Robson tworząc esej Tanato-mesjano-faszyzm. O ostatnich odsłonach polskiej symboliki mesjańskiej. Uzasadnieniem tytułu szkicu mają być m.in. uwagi o wierszu Jarosława Marka Rymkiewicza adresowanym do Jarosława Kaczyńskiego. Według Bielik-Robson „retoryka tego wiersza jest nie tyle mesjańska, ile wprost - faszystowska"78. Autorka wydaje się nie dostrzegać błędu rozumowania, który popełnia: skoro "retoryka” jest „wprost - faszystowska”, to nie analizie tropów mesjańskich, ale analizie chwytów retorycznych właściwych dla faszyzmu należało poświęcić szkic. Taki zabieg dostarczyłby zapewne argumentów, ale - pamiętajmy, w trzeciej sofistyce nie liczy się „siła argumentu”, ale

75 http:/ / wyborcza.pl/1,76842,12473370,Nalecz_haslo_Obudz_sie_Polsko_przypomina_haslo. html (data dostępu: 10.12.2014). Jest to realizacja jednocześnie dwóch chwytów erystycznych „argumentum ad Hitlerum", (zob. wcześniejsze uwagi) i "słabej analogii”. Jak wyjaśnia Barbara WitkowskaMaksimczuk (op. cit., s. 187): „W sofizmacie tym zestawia się jako podobne dwa przedmioty lub dwie idee, których podobieństwo jest jednak zbyt wątłe, by stanowić podstawę dla poprawnego rozumowania". Zob. P. H. Lewiński, Neosofistyka, op. cit., s. 169.

${ }^{76}$ Podajemy za: D. Baliszewski, A. K. Kunert, Ilustrowany przewodnik po Polsce stalinowskiej 1944-1956. T. 1: 1944-1945. Warszawa 1999, s. 567.

77 A zjawisko to narasta, choć bywa rozmaicie cieniowane, np. w wywiadzie-rzece, którego ostatnio udzieliła Agnieszka Graff, czytamy, iż w jej opinii: „Stoimy w obliczu fali... być może faszyzmu, która Polskę zalewa i jesteśmy wobec niej bezradni". Jestem stąd. Z Agnieszką Graff rozmawia Michat Sutowski. Warszawa 2014, s. 463.

78 Żałoba. Red. S. Sierakowski, A. Szczęśniak. Warszawa 2010, s. 211. 
jego siła oddziaływania. Naładowana silnym ładunkiem negatywnym etykieta79 może przekonać skuteczniej niż drobiazgowa analiza (której na dokładkę stałaby na przeszkodzie konwencja utworu i realia historyczne). Zgodnie z poetyką tekstów postmodernistycznych, autorzy niniejszego wywodu mogliby posłużyć się w zakończeniu wątku „faszystowskiego" przykładem zaczerpniętym z własnego doświadczenia i przywołać odbywające się w murach uczelni wyższej zebranie naukowe, na którym dyskutowano zaostrzenie kryteriów oceny. W kluczowym momencie jeden z dziekanów, tłumacząc się ze swoich decyzji, powiedział: „nikt nie chce być faszystą". Taki argument ma urok anegdoty równie cennej w trzeciej sofistyce, co zdolność rozbawienia słuchaczy. W tym wypadku chyba jednak nie uśmiech byłby adekwatnym efektem.

Z poziomu publicystycznego przejdźmy do popularnonaukowego, bo taki - ze względu na dobór źródeł, wybrany typ narracji, wybiórcze osadzenie w stanie badań, tak samo wybiórcze opatrywanie przypisami autocytatów czy wreszcie publicystyczne polemiki $\mathrm{w}$ odpowiedzi na zarzuty merytoryczne - reprezentują prace Jana Tomasza Grossa ${ }^{80}$. W tekstach Grossa kilkakrotnie pojawiają się następujące uwagi: „Myślę, że nadeszła wreszcie pora rewizji naszej wiedzy historycznej o epoce drugiej wojny światowej"81. Dalej autor wyjaśnia, dlaczego należy zrewidować naszą wiedzę: „dlatego, że los Żydów był w tych latach najbardziej tragiczny i [...] w polskiej historiografii omówiony niedostatecznie" ${ }^{\prime 2}$. Gross sam jednak stosuje - mistrzowsko posługując się sofistyczną metodą lustra, czyli stosowaniem takich samych zabiegów, jakie zarzuca przeciwnikowi - metodę przemilczenia ${ }^{83}$ i marginalizacji. W swych projektach nowej historii całkowicie prze-

79 Jest to chwyt erystyczny: „stronnicza nazwa (etykietowanie)”, jak wyjaśnia Beata WitkowskaMaksimczuk (op. cit., s. 191): „Etykietowanie to nadawanie nazwy poglądom, zjawiskom, sytuacjom, osobom, zgodnie z własną interpretacją; to kreowanie rzeczywistości przez używanie odpowiednich nazw".

${ }^{80}$ J. T. Gross, Sasiedzi: historia zagłady żydowskiego miasteczka. Sejny 2000; Strach: antysemityzm w Polsce tuz po wojnie: historia moralnej zapaści. Kraków 2008; Złote żniwa: rzecz o tym, co się działo na obrzeżach zagłady Żydów. Kraków 2011.

81 J. T. Gross, Upiorna dekada. Eseje o stereotypach na temat Żydów, Polaków, Niemców, komunistów i kolaboracji 1939-1948. Kraków 2007, s. 13.

82 Ibidem, s. 13.

${ }^{83}$ Bogaty katalog takich przemilczeń i innych manipulacji źródłami i faktami podają P. Gontarczyk, I. C. Pogonowski, T. Strzembosz, B. Musiał, St. Meducki i J. Żaryn. W: Cena "Strachu". Gross w oczach historyków. Wybór publikacji pod red. R. Jaworskiego. Warszawa 2008. Sprzeciw wobec metod stosowanych przez Grossa wyraził też Marek Jan Chodakiewicz. Ze względu na związki narracji Grossa z szerszym, omawianym tutaj nurtem metodologicznym, zacytujmy większy fragment jego wypowiedzi: "»Strach“ przyczyni się do utrwalenia na Zachodzie stereotypu "polskich obozów koncentracyjnych"i posłuży jako kolejny przykład eksterminacyjnego charakteru »polskiego antysemityzmu«. Co gorsza, jakiekolwiek sprzeciwy wobec skrajnych tez zawartych w "Strachu« zostaną uznane za dowód, że Polacy nadal pozostają antysemitami [...]. Naturalnie, można się cieszyć i zazdrościć, jak robi to »Gazeta Wyborcza« piórem jednego z recenzentów, że Gross do perfekcji opa- 
milcza np. męczeństwo Romów ${ }^{84}$, marginalizuje zaś męczeństwo Polaków, co więcej - do ostatniego celu używa ironii. Zacytujmy fragment wieńczący analizę eseju Jana Józefa Lipskiego: „[...] uzyskujemy wrażenie swoistej równowagi: po jednej stronie olbrzymia liczba zamordowanych Żydów, po drugiej zaś (wprawdzie liczebnie mniejsza) - grupa zamordowanych Polaków, złożona z ludzi wyjątkowych, bojowników o wolność, generała i tysięcy żołnierzy" 85 . Szczególne uprzywilejowanie ironii $\mathrm{w}$ czasach trzeciej sofistyki nie jest przypadkowe. Na to zjawisko już w połowie lat 70. zwrócił uwagę Walter Jackson Ong:

w przeszłości ironia wzbudzała niewielką uwagę badaczy, podczas gdy dzisiaj może być i często bywa obsesją, zastępując nawet metaforę jako ulubioną starą kość, w którą się wgryzali badacze. Narrator niewiarygodny [...], który, jak pokazał Wayne Booth, jest dużo bardziej funkcjonalny w prozie dzisiejszej niż kiedykolwiek w przeszłości, należy do głównych wytwórców olbrzymich efektów ironicznych, niewiarygodność stanowi bowiem istotę ironii: nie trzeba ufać oczywistemu sensowi ${ }^{86}$.

Walter Ong przypomniał - należy o tym pamiętać, także w odniesieniu do współczesnych ironistów - że „Eirōn w klasycznej grece był obłudnikiem, kimś, kto powiedział mniej niż pomyślał, a w konsekwencji był oszukańczym łajdakiem,

nował zasady dyskursu kulturowego, który dominuje obecnie na Zachodzie. Rzekomo w ten sposób najłatwiej tłumaczyć dzieje Polski cudzoziemcom, Polakom natomiast można pomóc rozliczyć się z ich jakoby ponurą przeszłością. Nie jest to prawda. Przykład profesor Ewy Thompson [...] pokazuje, że jest inaczej [...] historia Polski ze względu na zabory i pół wieku sowieckiej okupacji powinna być rozważana przez pryzmat modelu kolonialnego [...]. Tylko że Ewa Thompson nigdy nie odrzuciła arystotelesowskich zasad na rzecz postmodernizmu i dekonstrukcji. Cena "Strachu", op. cit., s. 272-273.

${ }^{84}$ Jest to zjawisko powszechne, które już niejednokrotnie zyskało sobie odpowiedź. Norman Finkelstein (Przedsiębiorstwo holokaust. Przeł. M. Szymański. Warszawa 2001, s. 92-94) pisał np.: „Hitlerowcy wymordowali około pół miliona Romów, co proporcjonalnie równa się stratom poniesionym przez Żydów. [...] uznanie ludobójstwa wobec Romów oznaczałoby utratę wyłączności Żydów na holokaust i w konsekwencji utratę żydowskiego »kapitału moralnego«. [...] gdyby hitlerowcy prześladowali tak samo Romów i Żydów, to ewidentnie podważałoby to dogmat, iż holokaust stanowił apogeum tysiącletniej nienawiści gojów do Żydów". Romowie powoli wkraczają do narracji o Holocauście, choć czasami ich dotychczasowa nieobecność zyskuje sobie zaskakujące wyjaśnienia. D. L. Bergen (Wojna i ludobójstwo. Krótka historia Holokaustu. Przeł. R. Witkowski, M. Sosnowska. Poznań 2011, s. 31) wielokrotnie wspomina o męczeństwie i śmierci Romów, brak solidnych opracowań na temat Zagłady Romów wyjaśniając na przykład tak: „Wydaje się, że tradycja romska zawsze była bardziej powiązana z teraźniejszością, a nie z przeszłością, bardziej mówiona niż spisana. Wieki prześladowań spowodowały, że zachowywano ograniczone kontakty z ludźmi spoza tej wspólnoty". Badaczka stara się przekonać, że to "tradycja romska", a więc sami Romowie są winni temu, iż ich tragedia w czasach Holokaustu jest/ bywa przemilczana.

85 J. T. Gross, Upiorna dekada, op. cit., s. 21.

86 W. J. Ong, Od mimesis do ironii: pismo i druk jako powłoki głosu. W: Idem, Osoba - świadomość - komunikacja. Antologia. Wybór, wstęp, przekład i opracowanie J. Japola. Warszawa 2009, s. 103-104. 
przeciwieństwem osoby szczerej, uczciwej. Ironia - eirōn, była czymś odpychającym" 87.

Przemilczenie stosowane przez Grossa dotyczy też faktu, iż przepisywania Zagłady dokonywano już kilkakrotnie i nie zawsze $\mathrm{z}$ dobrym skutkiem. Tom Segev pisał

Wydaje się [...], że z dwóch lekcji Zagłady - humanistycznej i nacjonalistycznej - wygrała ta druga. „Dziedzictwo Zagłady” w formie w jakiej nauczane jest w szkołach i propagowane przez narodowe uroczystości, zachęca do zaściankowego szowinizmu. Częste powoływanie się na Zagładę $\mathrm{w}$ polityce izraelskiej może być mylące: nie jest łatwo odróżnić szczere rozpamiętywanie od manipulacji argumentami sięgającymi do Zagłady. Każdy, kto próbuje zrozumieć społeczeństwo Izraela, musi nauczyć się rozróżniania tych dwóch postaw ${ }^{88}$.

Zauważa także - co w analizowaniu tego, jak współcześnie funkcjonuje argumentacja odwołująca się do historii, nie jest bez znaczenia - że „W miarę jak Zagłada przechodzi do coraz odleglejszej historii, wnioski z niej płynące stają się argumentami w zaciekłej walce o kształt współczesnej polityki, ideologii i moralności"89, a uwaga ta nie dotyczy tylko debat toczących się współcześnie w Izraelu. Sprzyja temu obowiązujący $\mathrm{w}$ humanistyce paradygmat, przyznający przewage interpretacji nad obiektem (znakomicie pisała o tym już Maria Dąbrowska, zob. uwagi powyżej). Eric W. Rothenbuhler, dyskutując z poglądami Fisha, pisał:

Niektórzy badacze, tacy jak Fish [...], przyznają większe znaczenie interpretacji niż jej obiektowi. Jednak ze względu na cele, jakie stawia sobie komunikacja społeczna, należy pamiętać, że istnieje obiekt interpretacji, przedmiot fizyczny znajdujący się w fizycznym otoczeniu, posiadający zmysłowo rozpoznawalne cechy, bez których interpretacja nie byłaby możliwa. Nawet, jeżeli się okazuje, że obiekt tekstowy nie jest tym, czego oczekujemy - nie pozwala się nagiąć do woli czytającego, ponieważ nie pozostaje już w związku ze swoim autorem, niezależny od woli, która go niegdyś ukształtowała - interpretator ma swobodę interpretacji, która nie jest możliwa w sytuacjach interakcji społecznej $[\ldots]^{90}$.

Postmodernistyczne oderwanie od rzeczywistości, mimo deklaracji odejścia od "twardych" metodologii i ideologii, daje - szczególnie w odniesieniu do obszarów wcześniej silną ideologią zainfekowanych - podobne rezultaty, co ideologiczne dowodzenie jednej słusznej racji. Tu i tam mamy do czynienia $\mathrm{z}$ „racjonalizmem

\footnotetext{
87 Ibidem.
}

88 T. Segev, Siódmy milion. Przeł. B. Gadomska. Warszawa 2012, s. 483.

${ }^{89}$ T. Segev, Siódmy milion, op. cit., s. 16.

${ }^{90}$ E. W. Rothenbuhler, Komunikacja rytualna. Od rozmowy codziennej do ceremonii medialnej, op. cit., s. $87-88$. 
fikcji"91, przy wyrazistym zastosowaniu środków sofistycznych, realizujących się $\mathrm{w}$ podobnych dziedzinach, $\mathrm{z}$ których historia, w tym także historia literatury, jest jedną z najważniejszych.

Przejdźmy do poziomu naukowego, którego uczestnicy - jak chciałby Rorty powinni cechować się „szacunkiem dla poglądów kolegów, ciekawością, chęcią zapoznania się z nowymi danymi i ideami" ${ }^{22}$. Nie jest tajemnicą, że w przypadku historii literatury polskiej, pisanej pod dyktando stalinistów, szczególnie romantyzm narażony był na manipulacje. Michał Głowiński zauważał:

Stalinowska wizja polskich tradycji artystycznych była wysoce restrykcyjna, lansowano tak zwane kierunki postępowe i realistyczne [...], a w nich nie mieścił się na przykład barok, traktowany jako przejaw religianctwa, nie mieściła się duża część romantyzmu, nie tylko Krasiński i Norwid, ale także wiele rzeczy z dorobku Mickiewicza i Słowackiego ${ }^{93}$.

A w innym miejscu:

Pozytywna kwalifikacja tak zwanego romantyzmu postępowego była w owym czasie możliwa, bo nakładała się na frazes rewolucyjny, w okresie stalinowskim cieszący się jeszcze bujnym życiem. Paradoksalnie, łączenie rewolty romantycznej z „rewolucyjnością" stalinowską odbierało romantyzmowi wszelkie rewolucyjne treści, a pośrednio wprowadzało je we frazesowiczowskie uniwersum funkcjonujące $w$ tamtych czasach. I o to właśnie chodziło. Podział miał inne jeszcze dogodne strony. Pozwalał pozbyć się tych romantyków, którzy - jak Krasiński - byli programowo katoliccy, a w polityce konserwatywni. Zadaniem historii literatury stało się totalitaryzowanie przeszłości ${ }^{94}$.

Problem "programowo katolickiego" Krasińskiego powrócił jak bumerang w epoce ponowoczesnej. Paweł Śpiewak dość znacząco wskazał tak oto sformułowaną kwestię:

Najmocniej zabrzmiało [...] ostrzeżenie przed żydowską z ducha i ciała rewolucją w Nie-boskiej komedii Zygmunta Krasińskiego. Ten utwór - ku memu zdziwieniu uważany jest za wielki romantyczny dramat [...]. Obraz spisku pojawiający się w dramacie Krasińskiego przywodzi na myśl wydane wiele dziesiątków lat temu Protokoty mędrców Syjonu" 95 .

\footnotetext{
${ }_{91}$ Pojęcie to wprowadziła Maria Hirszowicz, Pułapki zaangażowania. Intelektualiści w stużbie komunizmu, op. cit., s. 109.

92 Por. przyp. 22.

${ }^{93}$ M. Głowiński, Październik 1956: wielkie otwieranie. W: Idem, Realia, dyskursy, portret. Studia i szkice. Kraków 2011, s. 42.

${ }^{94}$ M. Głowiński, Dzieje romantyzmu w PRL-u (Najkrótszy kurs). W: Idem, Realia, dyskursy, portrety, op. cit., s. 72.

${ }_{95}$ P. Śpiewak, Żydokomuna, op. cit., s. 32-33.
} 
Nie tylko wyrażenie prywatnej opinii wydaje się mało stosowne w dyskursie naukowym (dodatkowo: w dyskursie innej dyscypliny, choćby był to dyskurs postmodernistyczny), ale i dość dowolne porównanie ostatecznie dyskredytujące rzekomo „wielki romantyczny dramat”96. Przywołanie Protokołów - apokryfu w żaden sposób z dziełem Krasińskiego nie związanego - poetyka „przychodzenia na myśl" od wykazania jakichkolwiek związków jednak zwalnia - miało na celu postawienie dramatu romantycznego poza możliwością wszelkiej dyskusji, o czym boleśnie przekonał się Umberto Eco. To jego postmodernistyczna fikcja Cmentarz w Pradze - powieściowa hipoteza powstania Protokołów mędrców Syjonu nieroszcząca sobie żadnej pretensji do wyrażania prawdy historycznej, została odsądzona od czci i wiary, a jej autor okrzyknięty został w Pradze „niezamierzonym antysemitą" 97 , bo w swej powieści jednoznacznie nie skrytykował antysemickich Protokołów. Nietrudno zgadnąć, jaki los może spotkać dzieło literackie w obszarze kulturowym, w którym spory o antysemityzm osiągają apogeum.

Warto zwrócić uwagę na jeszcze jeden mechanizm perswazyjny, a mianowicie na zmiany dokonywane $\mathrm{w}$ kanonie literackim. Z jednej strony Paweł Śpiewak dziwi się, że Nie-boska „uważana jest za wielki romantyczny dramat” (forma bezosobowa sugeruje arbitralny automatyzm, Autor pomija milczeniem wieloletnią tradycję krytyczną; nie wydaje się też, by w jakikolwiek sposób respektował postulowane przez Fisha poszanowanie dla wspólnoty interpretacyjnej), z drugiej uznaje Andrzeja Wolicę za "zapomnianego, wybitnego prozaika [...] komunistę". $\mathrm{Z}$ jednej strony więc $\mathrm{z}$ kanonu wyrzucany jest dramat romantyczny i jego ideologia, z drugiej - do kanonu wpisywana jest proza (przy zapomnieniu agitacyjnej liryki) Wolicy i jej ideologia. Historyk nie widzi konfliktu pomiędzy przedmiotem swojej pracy - określanej jako naukowa - którą jest „interpretacja historyczna” pojęcia „żydokomuna", a wygłaszaniem dowolnych osobistych opinii w innej dziedzinie naukowej, którą jest historia literatury. Można powiedzieć, że w ramach trzeciej sofistyki taki chwyt jest o tyle skuteczny, o ile osiąga zamierzony efekt. Przy zmasowaniu działań, polegającym na powtarzaniu uogólnień i zastępowaniu analiz gotowymi wnioskami, ten efekt zapewne się pojawi. Alina Cała w przedmowie do swego dzieła - którego kwalifikację naukową wspiera przynależność instytucjonalna Autorki, finansowanie z programów badawczych, naukowa recenzja we fragmencie przedrukowana na okładce - zapowiada: „Osobną i bardzo ważną kategorię stanowią te utwory literackie, które w istotny sposób przyczyniły się do formowania wyobrażeń antysemickich, np. Nie-Boska komedia Zygmunta

${ }^{96}$ Inny historyk, Piotr Gontarczyk, ocenił, że praca Śpiewaka „jest książką skrajnie nierzetelną. Nie zgadzają się w niej fakty i daty, a tezy nie mają oparcia w źródłach". Gontarczyk wylicza długą listę tego rodzaju błędów rzeczowych. Zob. P. Gontarczyk, Stereotypy i propaganda. „Uważam Rze” 2012, nr 21, s. 56-59.

${ }^{97} \mathrm{http}$ // / www.polskatimes.pl/artykul/471805,swiat-wierzy-w-medrcow-syjonu-umberto-eco-ko mentuje-swoj-cmentarz-w-pradze,2,id,t,sa.html (data dostępu: 14.12.2014). 
Krasińskiego $[\ldots]^{\prime \prime 98}$. Czytelnik, który spodziewałby się dowiedzenia powyższej tezy w ponad ośmiusetstronicowym dziele Autorki, znajdzie w nim jednak tylko jeszcze jedno zdanie: „Trzeci z wieszczów Zygmunt Krasiński w Nie-Boskiej komedii (1835) nakreślił ponury wizerunek wyznawców judaizmu i neofitów, stając się jednym z prekursorów antyżydowskich teorii spiskowych" 99 . Na próżno szukać analiz tekstu czy jego recepcji, a dołączony do tego zdania przypis informuje $\mathrm{o}$ „antyneofickiej fobii” i odsyła do innych przykładów tejże fobii. W ten sposób wielopłaszczyznowe dzieło literackie, którego skomplikowaną problematykę wielokrotnie dyskutowano, także w kontekście stosunków polsko-żydowskich ${ }^{100}$, wymykające się jednoznacznej interpretacji i niełatwo poddające się prostym wykładniom ideologicznym, zostaje potraktowane jak pozbawiona jakichkolwiek wartości, monotematyczna agitka.

Jan Sowa, podejmując się ostatnio opisania historii Europy Środkowej, a zwłaszcza Polski jako miejsca kulturowego i cywilizacyjnego zapóźnienia, starał się wskazać, że rejon ten dotknięty jest „syndromem niedorozwoju, niepełności, niesamoistności, niepełnego ukształtowania, podrzędności [...], niedojrzałości"101. Taką diagnozę można przyłożyć do obszarów postkolonialnych (pozostawmy na marginesie dyskusję o tym, czy jest to diagnoza wystarczająco dobrze w książce uzasadniona ${ }^{102}$ i nie dotknięta np. "syndromem autostygmatyzacji”, także nieobcym kulturze postkolonialnej). Sowa wskazuje m.in na mechanizm porównywania, będący bezpośrednią konsekwencją regionalnego urazu:

Wszędzie znajdziemy oczywiście skłonność do konkurencji i porównywania się, jednak żaden Niemiec nie myślał nigdy tak obsesyjnie, że chce być jak Holender, a nie jak Szwajcar, a żaden Francuz nie upierał się, że bardziej jest podobny do Anglika niż do Hiszpana, jak bardzo Polacy chcieliby przypominać Europejczyków z Zachodu, a nie Rosjan, a Węgrzy Austriaków, a nie Rumunów ${ }^{103}$.

Chęć przypominania „Europejczyków z Zachodu” przybierać może różne formy, zwykle jednak takie, w których owa niższość jest podwajana. Być może dlatego masowy mord na Żydach w Jedwabnem (dla którego nie ma usprawiedliwienia, co chcemy mocno podkreślić) zyskuje sobie racjonalizację sugerującą degrengoladę całego narodu polskiego, a nie - jak w przypadku innych krwawych mordów historii Zachodu, np. odbywających się na masową skalę w czasie Rewolucji Francuskiej - formę wypracowania narzędzi zrozumienia mechanizmu. Gustaw

98 A. Cała, Żyd - wróg odwieczny? Antysemityzm w Polsce i jego źródta. Warszawa 2012, s. 12

${ }^{99}$ Ibidem, s. 226.

100 Zob. np. J. Fiećko, Krasiński przeciw Mickiewiczowi: najważniejszy spór romantyków. Poznań 2011.

101 J. Sowa, Fantomowe ciało króla: peryferyjne zmagania z nowoczesna formą. Kraków 2011, s. 18.

102 Zob. recenzję książki Sowy autorstwa Tomasza Zaryckiego („Stan Rzeczy” 2012, nr 1(3), s. 222-230).

103 Ibidem. 
Le Bon, opisując zbrodnie dokonane przez tłum, nie dochodzi do wniosku, że zbrodnie te niszczą wszystkie wartości kultury francuskiej, także i te reprezentowane przez rewolucję. Według niego „zbrodniczy tłum” kieruje się własnymi zasadami i prawami, które nie mają nic wspólnego z normami obowiązującymi w danym społeczeństwie. Zbrodnie dokonane przez tłum $w$ trakcie rewolucji nie obciążają więc kultury francuskiej, bo nie mają z nią nic wspólnego ${ }^{104}$. Jest to, oczywiście, stanowisko, z którym można dyskutować, ale nie takie, które jest wyjęte spod wszelkiej dyskusji pod groźbą ostracyzmu przyjmującego w "niedojrzałym” obszarze kulturowym np. formę umieszczenia w „raporcie o mowie nienawiści”, opatrzonej niepozbawionym ideologicznych skojarzeń tytułem: Zamiast procesu ${ }^{105}$.

Wyzwolenie - być może tylko pozornie - z mrocznego cienia stalinizmu, z politycznego, gospodarczego i mentalnego skolonizowania i pośpieszne połknięcie najnowszych nurtów myśli zachodniej (które już najnowsze nie były, o czym dowodnie przekonuje przesunięta o lat kilkadziesiąt polska recepcja tekstów np. Fisha) - obok neopragmatyzmu zrodziło neostalinizm, w którym anything goes zastąpione zostało restrykcyjnie ograniczającym but - „wszystko uchodzi, ale nie...”. W końcu nikt nie chce być „faszystą", "antysemitą", a w ponowoczesnym świecie nie wypada być także i patriotą. Mechanizmy trzeciej sofistyki i dowolność metodologiczna, która „na Zachodzie” utorowała drogę do oderwania refleksji interpretacyjnej od rzeczywistości niebezpiecznie grawitując ku zupełnej dowolności, w odniesieniu do naszego regionu dała jeszcze jeden efekt uboczny: odrodzenie sofistyki systemu pozornej demokracji zwanej, nie bez powodów tautologicznie, "ludową".

Możemy oczywiście uznać, że przed skrajnościami obroni nas etyka. Jak w 2006 relacjonowała poglądy Fisha Anna Burzyńska, czołowi twórcy i przedstawiciele neopragmatyzmu bardzo szybko zdali sobie sprawę - między innymi pod wpływem krytyki płynącej z różnych stron - że pragmatyka

pozbawiona etyki prowadzić może w niezbyt bezpieczne rejony. Trudno się dziwić, że najbardziej antyfundamentalistyczne i zarazem najbardziej pragmatystycznie nasta-

\footnotetext{
${ }^{104}$ G. Le Bon, Psychologia tłumu. Przeł. B. Kaprocki. Przejrzał i przedmową opatrzył S. Mika. Warszawa 1986, s. 125.

105 S. Kowalski, M. Tulli, Zamiast procesu. Raport o mowie nienawiści. Warszawa 2003. Dyskusja z całą książką przekraczałaby ramy tego artykułu, zwróćmy jednak uwagę na podstawowe chwyty w niej stosowane: ironia, podważanie wiarygodności świadectw historycznych na podstawie przyjętych założeń ideologicznych, efekt lustra. Autorzy nie zdają sobie też chyba sprawy, że tytuł odsyła do mało chwalebnego okresu historii - bez prawdziwych procesów, zastępowanych tylko procesami fingowanymi, doskonale obywają się wszelkie totalitaryzmy. Tak czuły na zabiegi stalinowskie Michał Głowiński nie tylko nie dostrzega nic niewłaściwego w sposobie tworzenia dyskursu "raportu”, ale pochwala jego ideę. Zob. M. Głowiński, Zawsze to samo (Wokót ksiązki Sergiusza Kowalskiego i Magdaleny Tulli „Zamiast procesu. Raport o mowie nienawiści). W: Tegoż, Realia, dyskursy, portrety. Studia i szkice, s. 198-216.
} 
wione orientacje już w końcu lat siedemdziesiątych bardzo wyraźnie zaczęły kierować się w stronę etyki. [...] zwrot etyczny stał się zarówno koniecznością, jak i jedną z najbardziej oczywistych konsekwencji pragmatyzmu, i to zarówno $\mathrm{w}$ filozofii, jak i w wiedzy o literaturze ${ }^{106}$.

Jeśli jednak zwrot ku etyce stał się „koniecznością”, a więc został niejako wymuszony przez sprzeciw "fundamentalistów", to oznacza, że ani neopragmatyzm, ani retoryka sofistyczna nie są skazane na sukces. Po drugie, parafrazując cytat, zwrot ku etyce $\mathrm{w}$ dość powszechnym odczuciu przywodzi na myśl raczej fundamentalistyczne skojarzenia. Neopragmatyzm zastawił sidła sam na siebie, dla własnych celów instrumentalizując etykę. Chyba że - a to prawdziwy chwyt sofistyczny, którym posłużyła się Anna Burzyńska - idąc tokiem jej rozumowania, stwierdzimy, że "Zwrot, który nazywamy etycznym [...] nie jest [...] w gruncie rzeczy zwrotem w stronę etyki [...]. Jest raczej »powrotem do moralności« i to [...] »moralności ujawnionej«, a więc - »moralności bez etyki«"107.

Używając innej terminologii, można powiedzieć, że optymizm krakowskiej badaczki bierze się z projektowania powszechnej zgody na zastąpienie metanarracji, jaką była etyka, małymi prywatnymi narracjami, jakimi są indywidualne moralności. Te jednak, czego już badaczka nie dopowiada, bardzo łatwo podatne są na ideologiczne i sytuacyjne instrumentalizacje i nie jest to wyłącznie założenie teoretyczne, ale codzienne doświadczenie każdego z nas.

\footnotetext{
106 A. Burzyńska, Anty-teoria literatury. Kraków 2006, s. 451.

107 Ibidem, s. 463.
} 